\title{
Electrochemical Technologies to Decrease the Chemical Risk of Hospital Wastewater and Urine
}

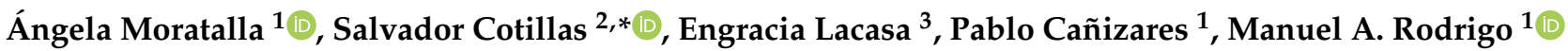 \\ and Cristina Sáez ${ }^{1, *(D)}$ \\ 1 Department of Chemical Engineering, Faculty of Chemical Sciences and Technologies, University of \\ Castilla-La Mancha, 13005 Ciudad Real, Spain; angela.moratalla@uclm.es (Á.M.); \\ pablo.canizares@uclm.es (P.C.); manuel.rodrigo@uclm.es (M.A.R.) \\ 2 Department of Chemical Engineering and Materials, Faculty of Chemical Sciences, Complutense University \\ of Madrid, 28040 Madrid, Spain \\ 3 Department of Chemical Engineering, Higher Technical School of Industrial Engineering, University of \\ Castilla-La Mancha, 02071 Albacete, Spain; engracia.lacasa@uclm.es \\ * Correspondence: salvacot@ucm.es (S.C.); cristina.saez@uclm.es (C.S.)
}

check for updates

Citation: Moratalla, Á.; Cotillas, S.; Lacasa, E.; Cañizares, P.; Rodrigo,

M.A.; Sáez, C. Electrochemical

Technologies to Decrease the

Chemical Risk of Hospital

Wastewater and Urine. Molecules 2021,

26, 6813. https://doi.org/10.3390/

molecules 26226813

Academic Editor: Boon Siang Jason Yeo

Received: 11 September 2021

Accepted: 9 November 2021

Published: 11 November 2021

Publisher's Note: MDPI stays neutral with regard to jurisdictional claims in published maps and institutional affiliations.

Copyright: (c) 2021 by the authors. Licensee MDPI, Basel, Switzerland. This article is an open access article distributed under the terms and conditions of the Creative Commons Attribution (CC BY) license (https:/ / creativecommons.org/licenses/by/ $4.0 /)$.

\begin{abstract}
The inefficiency of conventional biological processes to remove pharmaceutical compounds (PhCs) in wastewater is leading to their accumulation in aquatic environments. These compounds are characterized by high toxicity, high antibiotic activity and low biodegradability, and their presence is causing serious environmental risks. Because much of the PhCs consumed by humans are excreted in the urine, hospital effluents have been considered one of the main routes of entry of PhCs into the environment. In this work, a critical review of the technologies employed for the removal of $\mathrm{PhCs}$ in hospital wastewater was carried out. This review provides an overview of the current state of the developed technologies for decreasing the chemical risks associated with the presence of $\mathrm{PhCs}$ in hospital wastewater or urine in the last years, including conventional treatments (filtration, adsorption, or biological processes), advanced oxidation processes (AOPs) and electrochemical advanced oxidation processes (EAOPs).
\end{abstract}

Keywords: advanced oxidation processes; pharmaceuticals; wastewater; hospital urine

\section{Introduction}

Pharmaceutical compounds (PhCs) play an important role in keeping worldwide human health. Most of them are synthetic polar compounds manufactured by the relevant pharmaceutical companies, although some other medical drugs are produced using biotechnology from a natural biological source (e.g., insulin). PhCs can be classified depending on their chemical nature, therapeutic actions, target anatomical regions, rate of biodegradability, bioaccumulation potential or level of hazard. The most common classification is related to their mode of action (therapeutic actions), such as analgesics, antipyretic, antibiotics, antihistamines, anti-neoplastics, $\beta$-blockers, etc. Drugs get metabolized inside the human body by the action of specific enzymes, such as cytochromes which facilitate the development of bioreactions, evolving the therapeutic actions from the active pharmaceutical ingredients (APIs). The human body may only metabolize around $60-70 \%$ of the APIs and the residual drug is excreted in urine at $55-80 \%$ followed by feces at $4-30 \%$ [1-3]. Subsequently, a significant amount of the excreted PhCs enter the aquatic environment in various wastewater networks.

The presence of PhCs in aquatic environments ranges from 0.1 to $100 \mathrm{ng} / \mathrm{L}$ in natural water bodies (rivers and oceans), 100-1000 ng/L in groundwaters, 1-100 ng/L in effluents from wastewater treatment plants (WWTPs), or up to 10,000 ng/L in hospital effluents [4-7]. Their persistence in aquatic ecosystems is not only a consequence of a high rate of release but of their recalcitrant nature, with it being hard to attain complete mineralization. The 
detected PhCs remain biologically active and cause adverse effects in nontarget organisms within aquatic life as described under the EU-Directive 93/67/EEC. Likewise, the European Union Water Framework Directive reports an updated list of priority substances every four years $(2000 / 60 / E C)$ where PhCs are considered as potential pollutants. Depending on their therapeutic actions, they pose various degrees of alteration threat to the natural ecological balance. Among others, antibiotics act as endocrine disruptors and are responsible for the occurrence of antibiotic-resistant microbes [8,9]. Consequently, the World Health Organization (WHO) and many other regulatory authorities have identified PhCs as emerging pollutants since they still remain unregulated or are currently undergoing a regularization process $[10,11]$.

The discharges of human body excretions are directly flushed into municipal sewers towards the WWTPs. However, these treatment plants are designed to remove conventional pollutants from human waste, such as fats, biodegradable organic matters, nitrogen or phosphorus. Hence, the removal percentage of PhCs is lower than $10 \%$ since the biological treatment processes are not suitable to degrade complex organic molecular structures at low concentrations in water [11,12]. Among influents of WWTPs, hospital effluents are the main source of input for PhCs since they are not considered industrial effluents in most countries and, hence, regulations allow their direct discharge into the municipal sewer system without any prior treatment $[13,14]$. Specifically, hospital urine contains about 100 to 500 times more PhCs concentrations than domestic wastewater [15]. An efficient technological development is needed to pre-treat hospital urines as hotspots of PhCs release to ensure public health and reduce environmental risk. In this work, a review of the most recent technologies employed for the removal of PhCs in hospital wastewater (including urine matrices) is reported.

\section{Technologies for the Removal of Pharmaceuticals in Hospital Wastewater}

PhCs administered to patients admitted in the hospital are mainly excreted in urine and feces which are merged with other wastewater produced in different areas of hospital facilities, resulting in hospital wastewater (HWW) $[16,17]$. Specifically, HWW involves the effluents generated from sanitary activities (clinical treatments), toilets (urine, feces...), kitchen, laundry, or garden among others, which contain large amounts of chemicals, organic matter (including microorganisms: bacteria, virus and fungi) and inorganic ions [16]. Table 1 shows the typical composition of these effluents reported in the literature [18-24].

Table 1. Composition of HWW.

\begin{tabular}{|c|c|c|c|c|c|}
\hline Parameters & Units & Range & Compound & Units & Range \\
\hline $\mathrm{HCO}_{3}^{-}$ & \multirow{13}{*}{$\mathrm{mg} \mathrm{dm}^{-3}$} & $0-85$ & Saccharose & \multirow{2}{*}{$\mathrm{mg} \mathrm{dm}-3$} & $0-30$ \\
\hline $\mathrm{CO}_{3}{ }^{2-}$ & & $0-6$ & Glucose & & $0-30$ \\
\hline $\mathrm{Cl}^{-}$ & & $50-2000$ & COD & \multirow{2}{*}{$\mathrm{mg} \mathrm{O}_{2} \mathrm{dm}^{-3}$} & $300-420$ \\
\hline $\mathrm{SO}_{4}^{2-}$ & & $4-70$ & $\mathrm{BOD}_{5}$ & & $187-304$ \\
\hline $\mathrm{Ca}^{2+}$ & & $2-20$ & $\mathrm{pH}$ & \multirow[t]{2}{*}{-} & $7.0-7.5$ \\
\hline $\mathrm{K}^{+}$ & & $3-75$ & Antibiotics & & $0.0001-100$ \\
\hline $\mathrm{Mg}^{2+}$ & & $2-4$ & $\begin{array}{c}\text { Analgesics and } \\
\text { anti-inflammatories }\end{array}$ & \multirow{5}{*}{$\mathrm{mg} \mathrm{dm}-3$} & $0.00013-40$ \\
\hline $\mathrm{Na}^{+}$ & & $25-1200$ & Betablocker & & $10-20$ \\
\hline $\mathrm{S}^{2-}$ & & $0-15$ & Hypertensive & & $10-20$ \\
\hline $\mathrm{PO}_{4}^{3-}$ & & $5-30$ & Antidepressant & & $0.00387-0.008$ \\
\hline $\mathrm{NO}_{3}^{-}$ & & $0-10$ & Anticonvulsants & & $0.0006-0.005$ \\
\hline $\mathrm{NH}^{4+}$ & & $10-70$ & Enterococci & \multirow[b]{2}{*}{$\mathrm{UCF} \mathrm{mL}^{-1}$} & $10^{3}-10^{6}$ \\
\hline Urea & & $10-1300$ & Escherichia coli & & $10^{3}-10^{6}$ \\
\hline Humic acid & \multirow{2}{*}{$\mathrm{mg} \mathrm{dm} \mathrm{m}^{-3}$} & $0-10$ & Fecal coliforms & \multirow{2}{*}{$\mathrm{CFU} \mathrm{mL} \mathrm{L}^{-1}$} & $10^{3}-10^{4}$ \\
\hline Citric acid & & $0-10$ & Total coliforms & & $10^{5}-10^{7}$ \\
\hline
\end{tabular}

Chloride is the ion in the highest concentration, whereas urea is the main organic compound found in these effluents. This can be due to the use of large amounts of chlorine- 
based disinfectants in hospital facilities for cleaning activities and, the human urine from patients and the health staff which contains large concentrations of urea. Furthermore, HWW has a range of concentrations of 0.0001 to $100 \mathrm{mg} \mathrm{dm}^{-3}$ of pharmaceuticals in their composition, which mainly include antibiotics (up to $100 \mathrm{mg} \mathrm{dm}^{-3}$ ), analgesics and antiinflammatories (up to $40 \mathrm{mg} \mathrm{dm}^{-3}$ ), beta blockers and hypertensives (up to $20 \mathrm{mg} \mathrm{dm}^{-3}$ ), antidepressants (up to $0.008 \mathrm{mg} \mathrm{dm}^{-3}$ ) and anticonvulsants (up to $0.005 \mathrm{mg} \mathrm{dm}^{-3}$ ). These compounds are not degraded in conventional WWTPs and they are released to the environment [25]. For this reason, the development and application of efficient technologies for decreasing the risks associated to the presence of PhCs in sanitary effluents is critical from an engineering and environmental viewpoint.

HWW also contains high levels of microbiological contaminants, such as bacteria (Escherichia coli, Enterococci, fecal coliforms, total coliforms ... ), viruses (Enteroviruses, astroviruses, norovirus, hepatitis A ... ), fungi, etc. Thus, the development of these technologies could favor the elimination of not only PhCs but also microbiological content [26]. These microorganisms can be eliminated under milder conditions than PhCs by chlorination, ultraviolet, ozone, Fenton process, photocatalysis, etc. [27-29], or by in situ generation of oxidizing species (advanced electrochemical oxidation processes) [30-32].

The lack of legislation regulating the levels of PhCs in HWW promotes a rapid spread and accumulation of these compounds in the environment [17]. This also involves a health problem since favors the occurrence of ARB. Nonetheless, concern in the scientific community related to the development of highly efficient technologies for removing PhCs in hospital wastewater has increased considerably in recent years. Figure 1 summarizes the number of publications reported on the degradation of PhCs in hospital effluents (including hospital urine) and only urine reported from the early 70s.

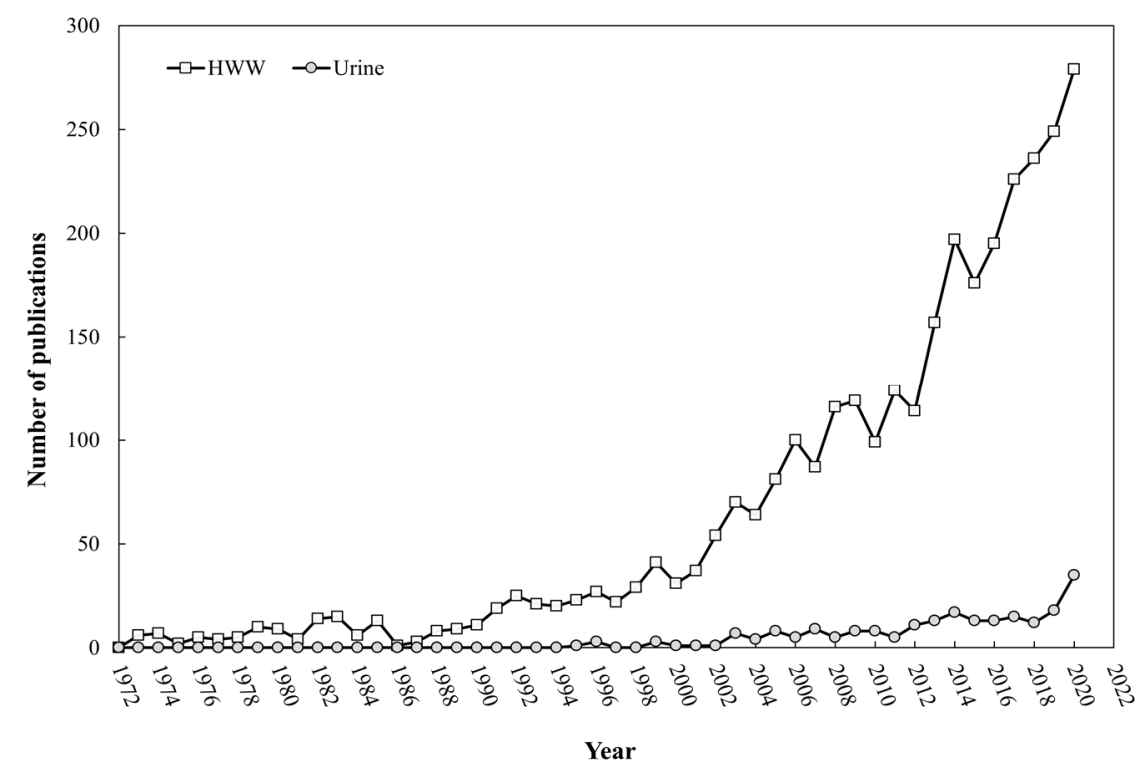

Figure 1. Publications related to the removal of PhCs in HWW and only hospital urine from 1970 to 2020 .

As can be observed, the number of publications has increased over the years, being more remarkable from the 2000s. Specifically, the manuscripts per year are lower than 50 up to 2001 and then, significantly increase until reach more than 250 publications in 2020. This reveals the growing interest from the scientific community in the treatment of HWW for the removal of PhCs as a pre-treatment before discharge to conventional WWTPs since the concentration of these pollutants is expected to be higher and, hence, easier to detect and treat. Even so, only $6.81 \%$ of the total publications summarized in Figure 1 referred to the removal of $\mathrm{PhCs}$ in urine. 


\subsection{Conventional Processes}

Biological and physical-chemical processes have been tested for the removal of PhCs in HWW due to their low cost and ease of operation. Table 2 summarizes the most relevant conventional technologies for this purpose reported in the literature until 2021.

Table 2. Conventional processes for the removal of PhCs in HWW.

\begin{tabular}{|c|c|c|c|c|c|c|}
\hline Effluent & Technology & Operation Parameters & Target Drug & Concentration & $\%$ Elimination & Ref. \\
\hline HWW & Electrocoagulation & $\begin{array}{l}\text { Aluminium electrodes } \\
\left(61 \mathrm{~cm}^{2}\right), \text { monopole } \\
\text { configuration. } 1000 \mathrm{~mA}\end{array}$ & Dexamethasone & $100 \mu \mathrm{g} \mathrm{L}^{-1}$ & $\sim 30$ (45 $\mathrm{min})$ & [18] \\
\hline HWW & Adsorption & $\begin{array}{c}\text { Porous activated carbons } \\
\text { prepared with } \\
\text { Caesalpinia ferrea. } \\
\text { CFAC } 0.5 \text { (ratio of } 0.5: 1.0 \text { of } \\
\mathrm{ZnCl}_{2} / \mathrm{CF} \text { at } 600^{\circ} \mathrm{C} \text { ) } \\
\mathrm{CFAC} 1.0 \text {. (ratio of } 1.0: 1.0 \text { of } \\
\mathrm{ZnCl}_{2} / \mathrm{CF} \text { at } 600^{\circ} \mathrm{C} \text { ) } \\
\mathrm{CFAC} 1.5 \text {. (ratio of } 1.5: 1.0 \text { of } \\
\mathrm{ZnCl}_{2} / \mathrm{CF} \text { at } 600^{\circ} \mathrm{C} \text { ) }\end{array}$ & Captopril & $25 \mathrm{mg} \mathrm{L}^{-1}$ & $\begin{array}{l}\text { CFAC.0.5/89.63 } \\
(60 \mathrm{~min}) \\
\text { CFAC. } 1.0 / 95.96 \\
(60 \mathrm{~min}) \\
\text { CFAC. } 1.5 / 97.67 \\
(60 \mathrm{~min}) \\
\text { CFAC.0.5/86.08 } \\
(60 \mathrm{~min}) \\
\text { CFAC. } 1.0 / 92.07 \\
(60 \mathrm{~min}) \\
\text { CFAC.1.5/94.22 } \\
(60 \mathrm{~min}) \\
\end{array}$ & [19] \\
\hline HWW & Biological & $\begin{array}{l}\text { Leptosphaerulina sp. (a } \\
\text { Colombian native fungus). } \\
\text { Conical flaks are inoculated } \\
\text { and incubated at } 28^{\circ} \mathrm{C} \text { and } \\
160 \text { rpm for } 8 \text { days. }\end{array}$ & Oxacillin & $16 \mathrm{mg} \mathrm{L}^{-1}$ & 100 (6 days) & [20] \\
\hline HWW & Adsorption & $\begin{array}{l}\text { Activated carbons derived } \\
\text { from Brazil nutshells: } \\
\mathrm{BNS1.0} \mathrm{(ratio} \mathrm{of} 1.0: 1.0 \text { of } \\
\mathrm{ZnCl}_{2} / \mathrm{BN} \text { at } 600{ }^{\circ} \mathrm{C} \text { ) } \\
\mathrm{BNS1.5} \text { (ratio of } 1.5: 1.0 \text { of } \\
\mathrm{ZnCl}_{2} / \mathrm{BN} \text { at } 600^{\circ} \mathrm{C} \text { ) }\end{array}$ & Acetaminophen & $\begin{array}{l}40 \mathrm{mg} \mathrm{L}^{-1} \\
80 \mathrm{mg} \mathrm{L}^{-1}\end{array}$ & $\begin{array}{l}\text { BNS1.0/98.29 } \\
(30 \text { min }) \\
\text { BNS1./98.83 } \\
(30 \text { min }) \\
\text { BNS1.0/96.38 } \\
(30 \text { min }) \\
\text { BNS1.5/97.04 } \\
(30 \text { min })\end{array}$ & [22] \\
\hline HWW & $\begin{array}{l}\text { Biodegradation } \\
\text { (Biological) }\end{array}$ & $\begin{array}{l}\text { Pseudomonas aeruginosa } \\
\left(1.5 \times 10^{8} \mathrm{CFU} \mathrm{mL}^{-1}\right) \\
\text { Microbial consortium } \\
(\text { Pseudomonas aeruginosa, } \\
\text { Citrobacter freundii, Klebsiella } \\
\text { pneumoniae, and Escherichia } \\
\text { coli) }\left(1.5 \times 10^{8} \mathrm{CFU} \mathrm{mL}^{-1}\right)\end{array}$ & Dicloxacillin & $40 \mathrm{mg} \mathrm{L}^{-1}$ & $100(3.75$ h) & {$[33]$} \\
\hline HWW & Adsorption & $\begin{array}{l}\text { Activated carbon filters with } \\
\text { different concentrations } \\
\text { of kenaf: } \\
\text { K-36-500/36\% } \\
\text { K- } 60-500 / 60 \% \\
\text { K- } 85-500 / 85 \%\end{array}$ & Paracetamol & $120 \mathrm{mg} \mathrm{L}^{-1}$ & $\begin{array}{l}\mathrm{K}-36-500 / \sim 42 \\
\quad(1000 \mathrm{~min}) \\
\mathrm{K}-60-500 / \sim 83 \\
\quad(1000 \mathrm{~min}) \\
\mathrm{K}-85-500 / \sim 68 \\
\quad(1000 \mathrm{~min})\end{array}$ & [34] \\
\hline HWW & Adsorption & $\begin{array}{l}\text { Sawdust adsorbent modified. } \\
\text { Adsorbent dose } 3.6 \mathrm{~g} \mathrm{~L}^{-1} \\
\text { and } \mathrm{pH} 8.3\end{array}$ & Tetracycline & $\sim 0.25 \mathrm{mg} \mathrm{L}^{-1}$ & $\sim 100$ (53 min) & [35] \\
\hline
\end{tabular}


Table 2. Cont.

\begin{tabular}{|c|c|c|c|c|c|c|}
\hline Effluent & Technology & Operation Parameters & Target Drug & Concentration & $\%$ Elimination & Ref. \\
\hline HWW & Adsorption & $\begin{array}{l}\text { Activated carbons with } \\
\text { Bertholletia excelsa capsules: } \\
\text { CCP.600 (ratio of } 1.0: 1.0 \text { of } \\
\mathrm{ZnCl}_{2} / \mathrm{CCP} \text { at } 600{ }^{\circ} \mathrm{C} \text { ) } \\
\mathrm{CCP} .700 \text { (ratio of } 1.0: 1.0 \text { of } \\
\mathrm{ZnCl}_{2} / \mathrm{CCP} \text { at } 700^{\circ} \mathrm{C} \text { ) }\end{array}$ & Amoxicillin & $\begin{array}{l}30 \mathrm{mg} \mathrm{L}^{-1} \\
60 \mathrm{mg} \mathrm{L}^{-1}\end{array}$ & $\begin{array}{c}\text { CCP.600/98.01 } \\
(30 \mathrm{~min}) \\
\text { CCP.700/98.60 } \\
(30 \mathrm{~min}) \\
\text { CСР.600/97.28 } \\
(30 \mathrm{~min}) \\
\text { CCP.700/97.76 } \\
(30 \mathrm{~min})\end{array}$ & [36] \\
\hline HWW & Adsorption & $\begin{array}{l}\text { Magnetic adsorbent was } \\
\text { prepared from Olive kernel } \\
\text { (MA-OK). Adsorbent } \\
\text { dose }=0.5 \mathrm{~g} \mathrm{~L}^{-1}, \mathrm{pH}=6\end{array}$ & Amoxicillin & $\begin{array}{l}200 \mathrm{mg} \mathrm{L}^{-1} \\
300 \mathrm{mg} \mathrm{L}^{-1} \\
400 \mathrm{mg} \mathrm{L}^{-1}\end{array}$ & $\begin{array}{l}95.31(90 \mathrm{~min}) \\
89.81(90 \mathrm{~min}) \\
97.90(90 \mathrm{~min})\end{array}$ & [37] \\
\hline HWW & Electrocoagulation & $\begin{array}{c}\text { Three aluminium plates } \\
\text { anodes and three iron } \\
\text { plates cathodes. } \\
\mathrm{V}=30 \mathrm{~V}, \mathrm{pH}=7\end{array}$ & Cefazolin & $0.0423 \mathrm{mg} \mathrm{L}^{-1}$ & $94(30 \mathrm{~min})$ & [38] \\
\hline HWW & Electrocoagulation & $\begin{array}{c}\text { Two aluminium plate } \\
\text { electrodes at } 12.5 \mathrm{~mA} \mathrm{~cm}^{-2} \\
\mathrm{pH}=7.78\end{array}$ & Ciprofloxacin & $154 \mu \mathrm{g} \mathrm{L}^{-1}$ & 100 (20 min) & [39] \\
\hline HWW & $\begin{array}{l}\text { Electrocoagulation- } \\
\text { persulfate }\end{array}$ & $\begin{array}{l}\text { Two aluminium anodes and } \\
\text { two aluminium cathodes at } \\
2.75 \mathrm{~mA} \mathrm{~cm}^{-2} ; \mathrm{pH}=7 . \mathrm{PS} \\
\text { concentration of } 0.84 \mathrm{mM}\end{array}$ & Ciprofloxacin & $3.5 \mathrm{mg} \mathrm{L}^{-1}$ & 81 (40 min) & [40] \\
\hline HWW & $\begin{array}{l}\text { Electrocoagulation- } \\
\text { adsorption }\end{array}$ & $\begin{array}{c}\text { Aluminium electrodes at } \\
\mathrm{pH} 7.8,15.5 \mathrm{~mA} \mathrm{~cm}^{-2} \\
0.7 \mathrm{~g} \mathrm{~L}^{-1} \text { chitosan }\end{array}$ & Cefazolin & $60 \mathrm{mg} \mathrm{L}^{-1}$ & 100 (23 min) & [41] \\
\hline Urine & Nanofiltration & $\begin{array}{l}\text { Stainless steel dead-end } \\
\text { stirred cell with an area } \\
\text { of } 54 \mathrm{~cm}^{2} \text { : } \\
\text { Desal } 5 \mathrm{DK} \text { membrane } \\
(150-300 \mathrm{Da}) \\
\text { NF270 membrane (300 Da) }\end{array}$ & $\begin{array}{l}\text { Paclitaxel } \\
\text { Etoposide } \\
\text { Cyclophos- } \\
\text { phamide } \\
\text { Ifosfamide }\end{array}$ & $0.5 \mathrm{mg} \mathrm{L}^{-1}$ & $\begin{array}{c}\text { Desal } 5 \text { DK } \\
>95 />95 / 96.6 / 96.3 \\
\text { NF270 } \\
>95 />95 / 81.1 / 82.5\end{array}$ & [42] \\
\hline
\end{tabular}

The use of a microbial consortium with Pseudomonas aeruginosa (P. aeruginosa), Citrobacter freundii, Klebsiella pneumoniae and Escherichia coli were tested for the removal of $40 \mathrm{mg} \mathrm{dm}^{-3}$ dicloxacillin in HWW, finding that it was possible to completely remove the antibiotic in less than $4 \mathrm{~h}$ [33]. Likewise, the biological degradation of dicloxacillin was also studied with $P$. aeruginosa but, in this case, an operating time of more than $50 \mathrm{~h}$ was required to achieve the complete antibiotic removal. These results reveal that the antibiotic degradation efficiency can be significantly improved using a microbial consortium under the operating conditions tested. Copete-Petuz et al. [20] evaluated a Colombian native fungus (Leptosphaerulina sp.) for the removal of $16 \mathrm{mg} \mathrm{dm}^{-3}$ oxacillin. Conical flasks were inoculated and incubated at $28^{\circ} \mathrm{C}$ with agitation $(160 \mathrm{rpm})$ for 8 days and, the antibiotic was completely degraded in 6 days (Figure 2). 


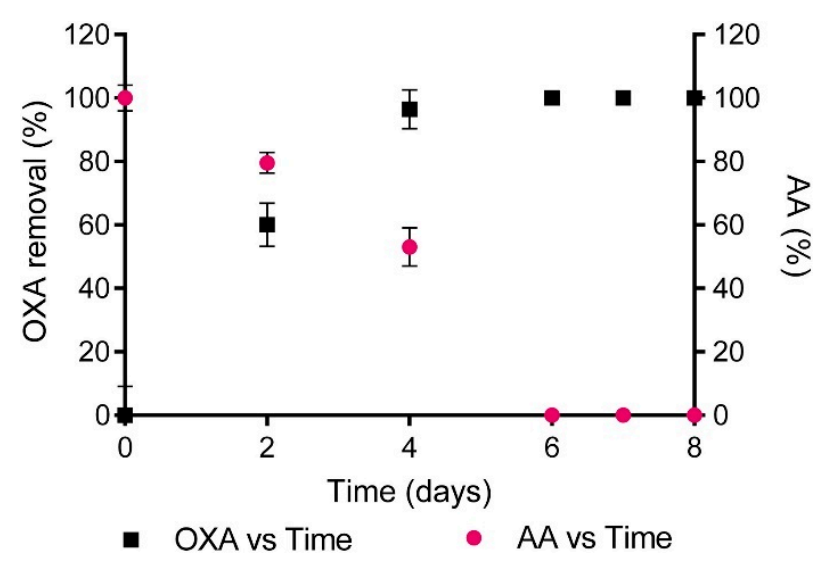

Figure 2. Evolution of oxacillin concentration and antibacterial activity (AA) as a function of the operating time during the biological degradation process by Leptosphaerulina sp. Reprinted with permission from ref. [20]. Copyright 2018 Elsevier.

Despite biological processes being effective and low-cost for the complete removal of PhCs in HWW, the operating times required to achieve a significant degradation of these compounds can be very high. Hence, other chemical processes have been evaluated for this purpose with the aim of obtaining high removal efficiencies and low operating times. The use of carbon-based materials has been reported for the adsorption of $\mathrm{PhCs}$ contained in HWW [19,34,35]. Lima et al. [22] studied the elimination of acetaminophen (40-80 $\mathrm{mg} \mathrm{dm}^{-3}$ ) from HWW using activated carbon derived from Brazil nutshells (BN) with $\mathrm{ZnCl}_{2}$. Removal percentages higher than $95 \%$ were achieved in 30 min using different ratios $\mathrm{ZnCl}_{2} / \mathrm{BN}$, regardless of the initial concentration of the pollutant. Furthermore, the removal of antibiotic amoxicillin (30-60 $\mathrm{mg} \mathrm{dm}^{-3}$ ) using activated carbon with Bertholletia excelsa capsules (CPP) was evaluated by Lima et al. The adsorbents were prepared with a ratio of $1: 1 \mathrm{ZnCl}_{2}: \mathrm{CPP}$, and the mixture was pyrolyzed at 600 and $700{ }^{\circ} \mathrm{C}$, reaching removal percentages higher than $97 \%$ in $30 \mathrm{~min}$ in all cases [36]. On the other hand, magnetic adsorbents from olive kernels (MA-OK) were employed for the removal of high concentrations of amoxicillin (200-400 $\mathrm{mg} \mathrm{dm}^{-3}$ ) in HWW by Jafari et al. [37]. They concluded that the use of adsorbent doses of $0.5 \mathrm{~g} \mathrm{dm}^{-3}$ at $\mathrm{pH} 6$ led to removal percentages within the range $89-98 \%$ in $90 \mathrm{~min}$.

Another interesting process for the elimination of PhCs in HWW is electrochemical coagulation $[18,38]$. This technology consists of the generation of coagulant species from the electrodissolution of a sacrificial anode that allows for the removal of pollutants by different physical-chemical mechanisms, such as charge neutralization or sweep flocculation [43]. The removal of $154 \mu \mathrm{g} \mathrm{dm}^{-3}$ ciprofloxacin in HWW using electrocoagulation with aluminium electrodes was reported by Ahmadzadeh et al. [39]. Total antibiotic removal was attained in $20 \mathrm{~min}$ when applying $12.5 \mathrm{~mA} \mathrm{~cm}^{-2}$ at $\mathrm{pH} 7.78$. Malakootian et al. [40] evaluated the application of electrocoagulation with aluminium electrodes and persulfate for the removal of $3.5 \mathrm{mg} \mathrm{dm}^{-3}$ ciprofloxacin in HWW, reaching an elimination percentage higher than $81 \%$ in $40 \mathrm{~min}$. During this process, persulfate can be activated electrochemically, favoring antibiotic degradation. Hence, ciprofloxacin is not only removed by physical separation promoted by electrocoagulation, but also can be chemically attacked by activated persulfate. Likewise, the treatment of HWW by the combination of electrocoagulation with other physical processes has been reported in the literature. Ahmadzadeh et al. [41] studied the removal of $60 \mathrm{mg} \mathrm{dm}^{-3}$ cefazolin in HWW by electrocoagulation with aluminium electrodes combined with adsorption using chitosan. The antibiotic was eliminated in $23 \mathrm{~min}$, applying a current density of $15.5 \mathrm{~mA} \mathrm{~cm}^{-2}$ and a chitosan concentration of $0.7 \mathrm{~g} \mathrm{dm}^{-3}$ at $\mathrm{pH} 7.8$.

Membrane technologies have also been tested for the removal of PhCs in HWW. The application of nanofiltration to the treatment of urine polluted with anticancer drugs was studied by Cristóvão et al. [42]. Two different membranes were evaluated (Desal 
5 DK and NF270) for the elimination of paclitaxel, etoposide, cyclophosphamide and ifosfamide with an initial concentration of $0.5 \mathrm{mg} \mathrm{dm}^{-3}$. The Desal 5 DK membrane has a molecular weight cut-off between 150 and $300 \mathrm{Da}$, whereas NF270 has a molecular weight cut-off of $300 \mathrm{Da}$. Removal percentages higher than $95 \%$ were attained for paclitaxel and etoposide, regardless the membrane used. However, Desal 5 DK membrane led to removal percentages higher than $96 \%$ for cyclophosphamide and ifosfamide whereas the use of the NF270 membrane achieved values higher than $80 \%$ for these compounds. This reveals that the Desal 5 DK membrane is more suitable for the removal of anticancer drugs from urine.

\subsection{Advanced Oxidation Processes (AOPs)}

Biological and physical-chemical technologies allow to remove PhCs from HWW, however, in many cases, the pollutants are not destroyed but only separated by adsorbents or flocs without altering their structure. For this reason, the application of Advanced Oxidation Processes (AOPs) to treat HWW has become a promising alternative to degrade PhCs. These technologies involve all processes that promote the generation of large amounts of highly reactive species for pollutants degradation. AOPs can be divided into two major groups: homogeneous and heterogeneous, which, in turn, can be classified into two different groups, depending on the energy requirements [44]. Table 3 summarizes the most relevant AOPs reported in the literature until 2021 for the degradation of PhCs in HWW.

Table 3. AOPS for the removal of PhCs in HWW.

\begin{tabular}{|c|c|c|c|c|c|c|}
\hline Effluent & Technology & Operation Parameters & Target Drug & Concentration & $\%$ Elimination & Ref. \\
\hline HWW & $\begin{array}{l}\text { Catalytic } \\
\text { Ozonation }\end{array}$ & $37.5 \mathrm{mg} \mathrm{O}_{3} / \mathrm{min}$ & Meropenem & $6 \mathrm{mg} \mathrm{L}^{-1}$ & 100 (11.7 min) & [45] \\
\hline HWW & $\begin{array}{l}\mathrm{H}_{2} \mathrm{O}_{2} / \mathrm{Fe}-\mathrm{Mn} \\
\text { binary oxide }\end{array}$ & $\begin{array}{l}{\left[\mathrm{H}_{2} \mathrm{O}_{2}\right]_{0}=6.0 \mathrm{mM}, 2.0 \mathrm{~g} \mathrm{~L}^{-1}} \\
\text { of Fe-Mn binary oxide }\end{array}$ & Sulfamethoxazole & $\begin{array}{l}0.1 \mathrm{mg} \mathrm{L}^{-1} \\
1.6 \mathrm{mg} \mathrm{L}^{-1}\end{array}$ & $\begin{array}{l}100(10 \mathrm{~min}) \\
92.8(10 \mathrm{~min})\end{array}$ & [46] \\
\hline HWW & $\mathrm{H}_{2} \mathrm{O}_{2} /$ magnetite & $\begin{array}{l}{\left[\mathrm{H}_{2} \mathrm{O}_{2}\right]=25 \mathrm{ppm} ;[\text { Magnetite] }} \\
=1 \mathrm{~g} \mathrm{~L}^{-1} ; \mathrm{pH}_{0}=5 ; \mathrm{T}=25^{\circ} \mathrm{C}\end{array}$ & Sulfamethoxazole & $5 \mathrm{mg} \mathrm{L}^{-1}$ & 30 (240 min) & [47] \\
\hline Urine & Photo-Fenton & $\begin{array}{c}\text { Simulated solar light at } \\
\text { constant UVA intensity of } \\
30 \mathrm{~W} \mathrm{~m}^{-2} \cdot 20 \mathrm{ppm} \mathrm{Fe} \mathrm{Fe}^{2+} \\
\mathrm{pH}=3 .\left[\mathrm{H}_{2} \mathrm{O}_{2}\right]_{0}=400 \mathrm{mg} \mathrm{L}^{-1} \\
\text { (replenished when it dropped } \\
\text { below } 100 \mathrm{mg} \mathrm{L}^{-1} \text { ). Two types } \\
\text { of urine: diluted } 1: 10 \\
\text { and undiluted. }\end{array}$ & Iohexol & $600 \mathrm{mg} \mathrm{L}^{-1}$ & $\begin{array}{l}\text { Diluted urine } \\
\text { 95 (120 min) } \\
\text { Undiluted } \\
\text { urine } 48 \\
(360 \mathrm{~min})\end{array}$ & {$[48]$} \\
\hline HWW & $\begin{array}{l}\text { Solar } \\
\text { Photo-Fenton }\end{array}$ & $\begin{array}{c}{\left[\mathrm{H}_{2} \mathrm{O}_{2}\right]_{0}=25 \mathrm{mg} \mathrm{L}^{-1}, \text { multiple }} \\
\text { addition of iron }=10 \mathrm{mg} \mathrm{L}^{-1} \\
\text { and } \mathrm{pH}=5.0 .\end{array}$ & Anastrozole & $50 \mu \mathrm{g} \mathrm{L}^{-1}$ & $\sim 50(120 \mathrm{~min})$ & [49] \\
\hline HWW & $\begin{array}{c}\text { Solar } \\
\text { Photo-Fenton } \\
\text { and adsorption }\end{array}$ & $\begin{array}{l}\text { Solar Photo Fenton process: } \\
\text { three } \mathrm{Fe}^{2+} \text { additions } \\
\left(5 \mathrm{mg} \mathrm{dm}{ }^{-3} \mathrm{Fe}^{2+} \text { each and }\right. \\
150 \mathrm{mg} \mathrm{dm}{ }^{-3} \text { ) } \\
\text { Adsorption: } 14 \mathrm{mg} \text { of avocado } \\
\text { seed activated carbon }\end{array}$ & $\begin{array}{l}\text { Flutamide and } \\
\text { transformation } \\
\text { products }\end{array}$ & $500 \mu \mathrm{g} \mathrm{L}^{-1}$ & $\begin{array}{c}\text { Solar } \\
\text { Photo-Fenton: } \\
58 \text { (120 min) } \\
\text { Adsorption: } \\
\text { >97 (40 min) }\end{array}$ & {$[50]$} \\
\hline HWW & $\mathrm{UV} / \mathrm{H}_{2} \mathrm{O}_{2}$ & $\begin{array}{l}\text { Photo-oxidation process. } \\
\mathrm{UV}_{254} \text { lamp }(15 \mathrm{~W}) \\
{\left[\mathrm{H}_{2} \mathrm{O}_{2}\right]_{0}=25 \mathrm{mg} \mathrm{L}^{-1}}\end{array}$ & $\begin{array}{l}\text { Metoprolol } \\
\text { Metoprolol acid }\end{array}$ & $\begin{array}{l}2.0 \mu \mathrm{g} \mathrm{L}^{-1} \\
2.0 \mu \mathrm{g} \mathrm{L}^{-1}\end{array}$ & $\begin{array}{l}71.6(10 \mathrm{~min}) \\
88.7(10 \mathrm{~min})\end{array}$ & [51] \\
\hline
\end{tabular}


Table 3. Cont.

\begin{tabular}{|c|c|c|c|c|c|c|}
\hline Effluent & Technology & Operation Parameters & Target Drug & Concentration & \% Elimination & Ref. \\
\hline HWW & $\begin{array}{l}\text { UV }(275 \mathrm{~nm}) / \\
\text { Chlorination }\end{array}$ & $\begin{array}{l}\text { Glass reactor with magnetic } \\
\text { stirrer. UV-LED of } 275 \mathrm{~nm} \text {. } \\
\text { [Free available chlorine] = } \\
15 \mathrm{mg} \mathrm{L}^{-1}, \mathrm{pH}=7\end{array}$ & Ciprofloxacin & $10 \mathrm{mg} \mathrm{L}^{-1}$ & 100 (60 min) & [52] \\
\hline \multirow{2}{*}{ HWW } & \multirow{2}{*}{$\begin{array}{l}\mathrm{TiO}_{2-}^{-} \\
\text {photocatalysis }\end{array}$} & \multirow{2}{*}{$\begin{array}{l}\text { Laboratory-scale photoreactor. } \\
\text { UV lamp }(365 \mathrm{~nm})=125 \mathrm{~W} \text {. } \\
\text { pH 7.6, } \mathrm{TiO}_{2} \text { dosage is } \\
563 \mathrm{mg} \mathrm{L}^{-1}\end{array}$} & & $10 \mathrm{mg} \mathrm{L}^{-1}$ & & \multirow{2}{*}{ [53] } \\
\hline & & & Amoxicillin & $10 \mathrm{mg} \mathrm{L}^{-1}$ & 90 (150 min) & \\
\hline Urine & $\begin{array}{c}\mathrm{TiO}_{2-}^{-} \\
\text {photocatalysis }\end{array}$ & $\begin{array}{c}{\left[\mathrm{TiO}_{2}\right]: 0.5 \mathrm{~g} \mathrm{~L}^{-1}, \mathrm{pH}: 6.1,} \\
\text { UVA light: } 75 \mathrm{~W}\end{array}$ & Losartan & $43.38 \mu \mathrm{mol} \mathrm{L}^{-}$ & 35 (20 min) & [54] \\
\hline Urine & UV/Persulfate & $\begin{aligned} {[P S]=} & 500 \mu \mathrm{mol} \mathrm{L}-1, \mathrm{pH}=6.1 \\
& \text { UVC light: } 60 \mathrm{~W} .\end{aligned}$ & Losartan & $43.38 \mu \mathrm{mol} \mathrm{L}-1$ & 35 (20 min) & {$[54]$} \\
\hline HWW & $\begin{array}{l}\text { Nano- } \\
\text { photocatalysis }\end{array}$ & $\begin{array}{l}\text { ZnO concentration on the plat: } \\
0.6 \mathrm{~g} \mathrm{~L}^{-1} \cdot \mathrm{pH}=11 \text {, reaction } \\
\text { time } 90 \mathrm{~min} .\end{array}$ & Ciprofloxacin & $3 \mathrm{mg} \mathrm{L}^{-1}$ & 90.25 (90 min) & [55] \\
\hline HWW & $\begin{array}{l}\text { Thermally } \\
\text { activated } \\
\text { persulfate }\end{array}$ & $\begin{array}{l}\text { Sodium persulfate }=10 \mathrm{mM} \text {, } \\
\text { phosphate buffer }=50 \mu \mathrm{M} . \\
20 \mathrm{~mL}, \mathrm{pH}=7.5, \mathrm{~T}=70^{\circ} \mathrm{C} .\end{array}$ & Naproxen & $50 \mu \mathrm{M}$ & 100 (10 min) & [56] \\
\hline HWW & $\begin{array}{l}\mathrm{UV} / \mathrm{H}_{2} \mathrm{O}_{2} \text { and } \\
\text { biological } \\
\text { process }\end{array}$ & $\begin{array}{c}\text { Photo-oxidation process: } \\
\text { Immersion-type photo-reactor. } \\
\text { UV lamp }(15 \mathrm{~W}),\left[\mathrm{H}_{2} \mathrm{O}_{2}\right] \text { : } \\
15 \mathrm{mg} \mathrm{L}^{-1} \text { with a reaction } \\
\text { time of } 10 \text { min. } \\
\text { Bioreactor with activated } \\
\text { sludge were operated as a } \\
\text { batch with reaction time } \\
\text { of } 24 \mathrm{~h}\end{array}$ & $\begin{array}{c}\text { Metoprolol } \\
\text { Metropolol acid }\end{array}$ & $\begin{array}{l}2.0 \mu \mathrm{g} \mathrm{L}^{-1} \\
2.0 \mu \mathrm{g} \mathrm{L}^{-1}\end{array}$ & $\begin{array}{c}\text { Bioreactor- } \\
\mathrm{UV} / \mathrm{H}_{2} \mathrm{O}_{2} \\
85.7 \\
98.5 \\
\mathrm{UV} / \mathrm{H}_{2} \mathrm{O}_{2}- \\
\text { Bioreactor } \\
85.6 \\
99.5\end{array}$ & [57] \\
\hline
\end{tabular}

Ozone $\left(\mathrm{E}^{0}: 2.08 \mathrm{~V}\right)$ is a powerful oxidant that can be decomposed to form the hydroxyl radical $\left(\mathrm{E}^{0}: 2.80 \mathrm{~V}\right)$, a more oxidizing and non-selective species capable of destroying organic pollutants contained in water bodies. This process can be carried out in alkaline media to promote the rapid decomposition of ozone (non-catalytic ozonation) or using solid catalysts (catalytic ozonation) [58,59]. Agudelo et al. [45] evaluated the removal of $6 \mathrm{mg} \mathrm{dm}^{-3}$ meropenem in HWW by catalytic ozonation using powder activated carbonPortland cement as a catalyst. They applied an ozone flow rate of $37.5 \mathrm{mg} \mathrm{O}_{3} \mathrm{~min}^{-1}$ and reached the total removal of antibiotics in less than $12 \mathrm{~min}$.

Another oxidant species that can be activated to produce large amounts of hydroxyl radicals is hydrogen peroxide $\left(\mathrm{E}_{0}: 1.78 \mathrm{~V}\right)$. The use of iron-based catalysts for this purpose is well known as Fenton reaction (Equation (1)) [60,61].

$$
\mathrm{H}_{2} \mathrm{O}_{2}+\mathrm{Fe}^{2+} \rightarrow \cdot \mathrm{OH}+\mathrm{Fe}^{3+}+\mathrm{OH}^{-}
$$

The degradation of antibiotic sulfamethoxazole by Fenton process was reported by Wu et al. [46] who studied the activation of hydrogen peroxide by a Fe-Mn binary oxide (FMBO). The initial amount of hydrogen peroxide employed was $6 \mathrm{mM}$ with a catalyst concentration of $2 \mathrm{~g} \mathrm{dm}^{-3}$. The complete degradation of $0.1 \mathrm{mg} \mathrm{dm}^{-3}$ sulfamethoxazole was attained in $10 \mathrm{~min}$ and a percentage removal higher than $90 \%$ was achieved at the same time (10 min) during the treatment of HWW polluted with $1.6 \mathrm{mg} \mathrm{dm}^{-3}$ sulfamethoxazole. Muñoz et al. [47] evaluated the removal of $5 \mathrm{mg} \mathrm{dm}^{-3}$ sulfamethoxazole in HWW by Fenton process at $\mathrm{pH} 5$ using $25 \mathrm{mg} \mathrm{dm}{ }^{-3} \mathrm{H}_{2} \mathrm{O}_{2}$ and $1 \mathrm{~g} \mathrm{dm}^{-3}$ magnetite as catalyst (heterogeneous Fenton). They reached a removal percentage of around 30\% in $240 \mathrm{~min}$ (Figure 3). 


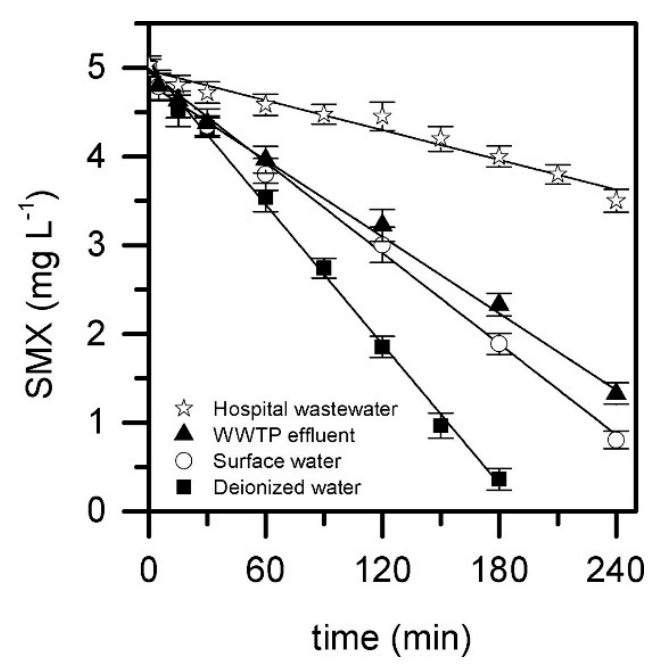

Figure 3. Evolution of SMX upon CWPO with magnetite in different real aqueous matrices $\left([\mathrm{SMX}]_{0}=5 \mathrm{mg} \mathrm{L}^{-1} ;\left[\mathrm{H}_{2} \mathrm{O}_{2}\right]_{0}=25 \mathrm{mg} \mathrm{L}^{-1} ;[\text { magnetite }]_{0}=1 \mathrm{~g} \mathrm{~L}^{-1} ; \mathrm{pH}_{0}=5 ; \mathrm{T}=25^{\circ} \mathrm{C}\right)$. Experimental (symbols) and model fit (solid lines). Reprinted with permission from ref. [47]. Copyright 2018 Elsevier.

The Fenton process can be enhanced by the irradiation of UV light (photo-Fenton) since it promotes the massive production of hydroxyl radicals from the photoactivation of both hydrogen peroxide and catalyst, depending on the wavelength applied [62-64]. Papoutsakis et al. [48] studied the treatment of urine polluted with iohexol $\left(600-6000 \mathrm{mg} \mathrm{dm}^{-3}\right)$ by photo-Fenton under simulated solar light. A constant UVA intensity of $30 \mathrm{~W} \mathrm{~m}^{-2}$ was applied to polluted urine containing $400 \mathrm{mg} \mathrm{dm}^{-3} \mathrm{H}_{2} \mathrm{O}_{2}$ and $20 \mathrm{mg} \mathrm{dm}^{-3} \mathrm{Fe}^{2+}$ at $\mathrm{pH}$. Results showed that it was possible to attain removal percentages higher than $95 \%$ in $120 \mathrm{~min}$ during the treatment of diluted urine $\left(600 \mathrm{mg} \mathrm{dm}^{-3}\right.$ iohexol) and values around $50 \%$ in $360 \mathrm{~min}$ when treating urine directly $\left(6000 \mathrm{mg} \mathrm{dm}^{-3}\right)$. On the other hand, the treatment of HWW polluted with $50 \mu \mathrm{g} \mathrm{dm}^{-3}$ anastrozole by solar photo-Fenton was reported by Sanabria et al. [49]. They used $25 \mathrm{mg} \mathrm{dm}{ }^{-3} \mathrm{H}_{2} \mathrm{O}_{2}$ and a constant catalyst concentration of $10 \mathrm{mg} \mathrm{dm}^{-3}$ at $\mathrm{pH} \mathrm{5}$, achieving removal percentages around 50\% in $120 \mathrm{~min}$.

Several studies have shown that the combination of the Solar photo-Fenton process with tertiary processes (such as adsorption) can improve the removal of persistent pharmaceutical compounds [65-67]. In this context, Della-Flora et al. [50] investigated the degradation of Flutamide $\left(500 \mu \mathrm{g} \mathrm{L}^{-1}\right)$ and its transformation products (TPs) from HWW by Solar photo-Fenton combined with adsorption with activated carbon. Solar photoFenton was applied using three $\mathrm{Fe}^{2+}$ additions approach $\left(5 \mathrm{mg} \mathrm{L}^{-1}\right.$ of $\mathrm{Fe}^{2+}$ each, with an initial $\mathrm{H}_{2} \mathrm{O}_{2}$ concentration of $150 \mathrm{mg} \mathrm{L}^{-1}$ ) achieving $58 \%$ degradation in $120 \mathrm{~min}$. For the adsorption process, $14 \mathrm{mg}$ of avocado seed activated carbon was used and a contact time of $40 \mathrm{~min}$, obtaining Flutamide and TPs degradation rates of over $97 \%$.

The irradiation of UV light has also been tested in the photoactivation of hydrogen peroxide $\left(\mathrm{UVC} / \mathrm{H}_{2} \mathrm{O}_{2}\right)$ or chlorine $\left(\mathrm{UVC} / \mathrm{Cl}_{2}\right)$ for the treatment of $\mathrm{HWW}$. In these cases, a wavelength around $254 \mathrm{~nm}$ (UVC) is required to ensure the decomposition of hydrogen peroxide and chlorine to free radicals [68,69]. Jaén-Gil et al. [51] reported the degradation of metoprolol $\left(2 \mu \mathrm{g} \mathrm{dm}^{-3}\right)$ and metoprolol acid $\left(2 \mu \mathrm{g} \mathrm{dm}{ }^{-3}\right)$ in $\mathrm{HWW}$ by $\mathrm{UVC} / \mathrm{H}_{2} \mathrm{O}_{2}$ using $25 \mathrm{mg} \mathrm{dm}^{-3} \mathrm{H}_{2} \mathrm{O}_{2}$ and a $\mathrm{UVC}_{254} \mathrm{~nm}$ lamp of $15 \mathrm{~W}$. Removal percentages higher than $70 \%$ were achieved in $10 \mathrm{~min}$, being the degradation of metoprolol acid faster than that of metoprolol (88.7 vs. $71.6 \%$ ). Kim et al. [52] evaluated the treatment of ciprofloxacin polluted $\mathrm{HWW}$ by $\mathrm{UVC} / \mathrm{Cl}_{2}$ at $\mathrm{pH} 7$ in a UV-LED reactor (Figure 4). Chlorine doses of $15 \mathrm{mg} \mathrm{dm}^{-3}$ were added to the effluents under UV-LED irradiation $(275 \mathrm{~nm})$, reaching the complete removal of $10 \mathrm{mg} \mathrm{dm}^{-3}$ ciprofloxacin in $60 \mathrm{~min}$. 


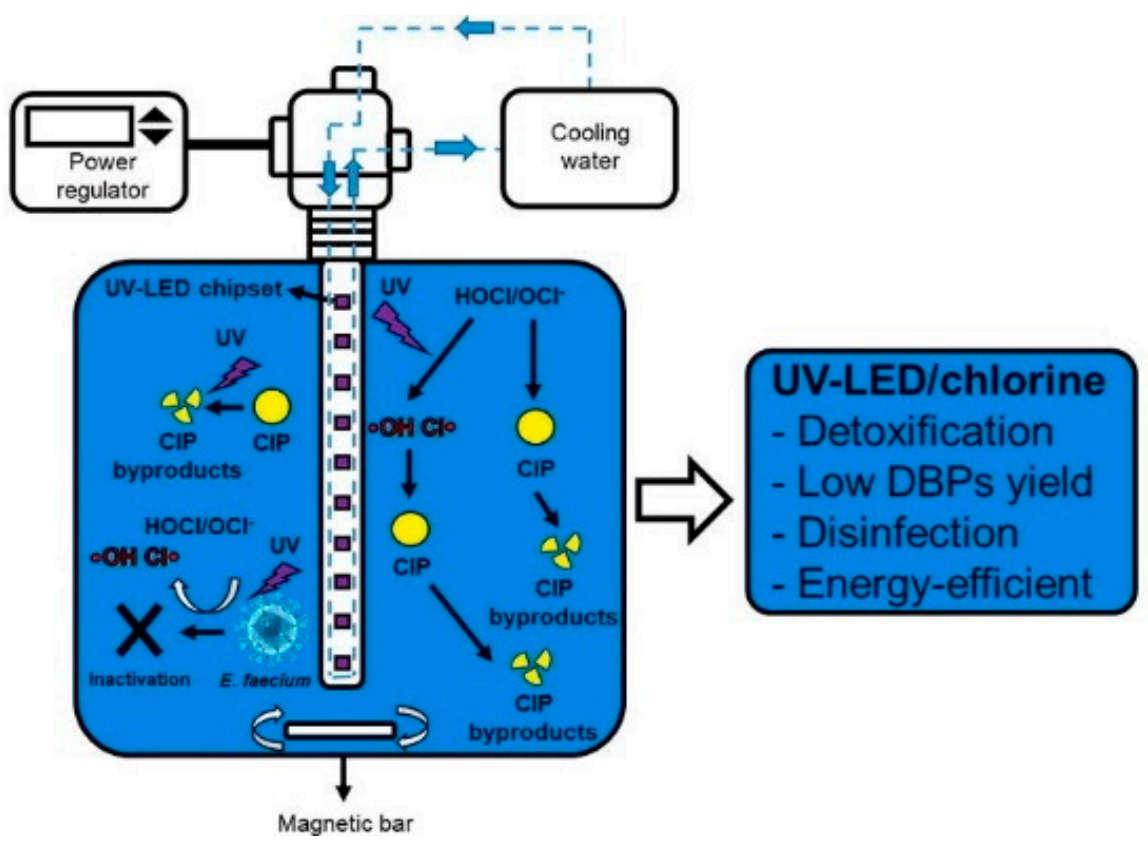

Figure 4. Schematic diagram of UV-LED reactor. Reprinted with permission from ref. [52]. Copyright 2020 Elservier.

Another AOP that employs the irradiation of UV light to produce reactive oxidizing species (ROS) is photocatalysis. During this process, a semiconductor material absorbs UV light for moving an electron from the valence gap to the conduction band. This generates a positive hole in the valence band that can oxidize $\mathrm{H}_{2} \mathrm{O}$ or $\mathrm{OH}^{-}$, favoring the production of ROS [70]. The most common photocatalyst used for the removal of organic pollutants in wastewater is titanium dioxide $\left(\mathrm{TiO}_{2}\right)$ [71]. Chinnaiyan et al. [53] reported the removal of metformin $\left(10 \mathrm{mg} \mathrm{dm}^{-3}\right)$ and amoxicillin $\left(10 \mathrm{mg} \mathrm{dm}^{-3}\right)$ in HWW by photocatalysis using $\mathrm{TiO}_{2}$ as photocatalyst $\left(563 \mathrm{mg} \mathrm{dm}^{-3}\right.$ ) and a UV lamp of $125 \mathrm{~W}(365 \mathrm{~nm})$. The process was carried out at $\mathrm{pH} 7.6$ and the results showed that it was possible to attain removal percentages higher than $90 \%$ for both PhCs in $150 \mathrm{~min}$. Furthermore, the elimination of lorsatan from urine by photocatalysis with $\mathrm{TiO}_{2}$ was studied by Guateque-Londoño et al. [54]. They used $0.5 \mathrm{~g} \mathrm{dm}^{-3} \mathrm{TiO}_{2}$ and UVA light irradiation $(75 \mathrm{~W})$ at $\mathrm{pH} 6.1$ for the degradation of $43.38 \mu \mathrm{mol} \mathrm{dm}{ }^{-3}$ lorsatan, reaching removal percentages around $35 \%$ in $20 \mathrm{~min}$. Other photocatalysts based on $\mathrm{ZnO}$ have also been tested for the removal of organic pollutants. Gharaghani et al. [55] evaluated the elimination of $3 \mathrm{mg} \mathrm{dm}^{-3}$ ciprofloxacin in HWW using $\mathrm{ZnO}$ nanoparticles at $\mathrm{pH} 11$. The antibiotic was almost completely removed $(90.25 \%)$ in 90 min under the operating conditions tested.

On the other hand, AOPs based on persulfate have been studied for the treatment of HWW and urine. This oxidant species can be photoactivated by the irradiation of UV light, favoring the production of free sulfate radicals (Equation (2)) which can attack organic pollutants contained in the effluents.

$$
\mathrm{S}_{2} \mathrm{O}_{8}{ }^{2-}+\mathrm{h} v \rightarrow 2 \mathrm{SO}_{4}^{-}
$$

Guateque-Londoño et al. [54] evaluated the degradation of $43.38 \mu \mathrm{mol} \mathrm{dm}{ }^{-3}$ lorsatan in urine using $500 \mu \mathrm{mol} \mathrm{dm}{ }^{-3} \mathrm{~S}_{2} \mathrm{O}_{8}{ }^{2-}$ and UVC light $(60 \mathrm{~W})$ at $\mathrm{pH}$ 6.1. Removal percentages around $35 \%$ were achieved in $20 \mathrm{~min}$. Persulfate can also be activated by heating to produce sulfate radicals [72,73]. The elimination of $50 \mu \mathrm{M}$ naproxen in HWW by thermally activated persulfate was reported by Ghauch et al. [56]. An initial concentration of $10 \mathrm{mM} \mathrm{S}_{2} \mathrm{O}_{8}{ }^{2-}$ was added to the effluent at $\mathrm{pH} 7.5$ and, the temperature was increased up to $70{ }^{\circ} \mathrm{C}$. The complete removal of $\mathrm{PhC}$ was attained in $10 \mathrm{~min}$ (Figure 5). 


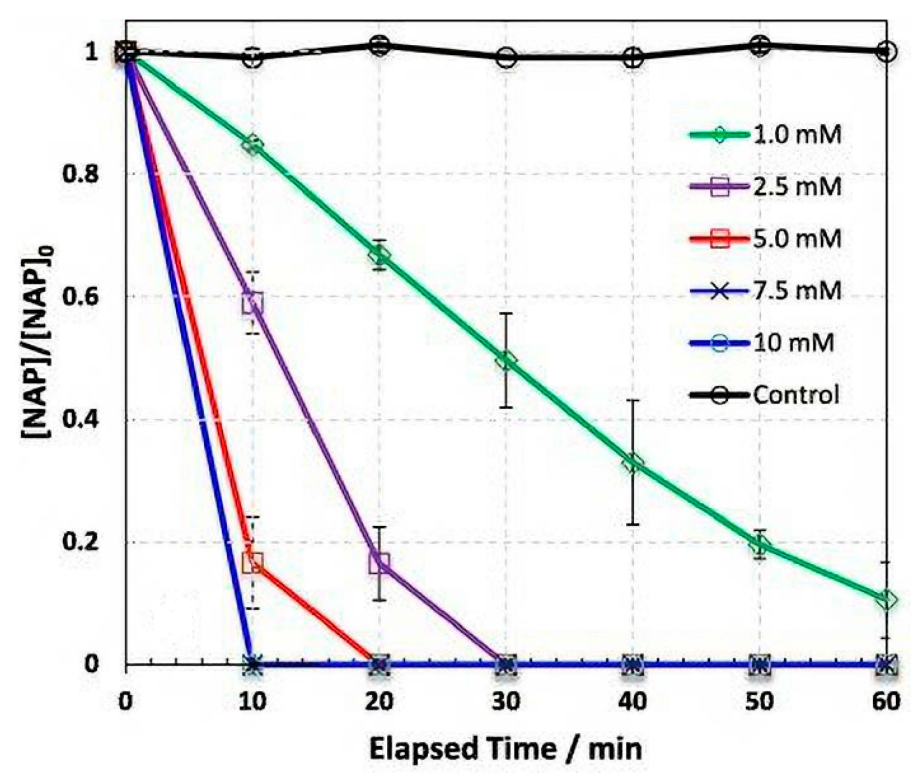

Figure 5. Evolution of naproxen concentration as function of the elapsed time during the treatment of hospital effluents. [NAP] $0=50 \mu \mathrm{IM}, \mathrm{pH} 7.50, \mathrm{~T}=70^{\circ} \mathrm{C}$. Reprinted with permission from ref. [56]. Copyright 2015 Elsevier.

The integration of biological processes with AOPs can also increase the efficiency of the treatments. Jaén-Gil et al. [57] evaluated the combination of $\mathrm{UV} / \mathrm{H}_{2} \mathrm{O}_{2}$ with a biological process (with activated sludge) for the removal of metropolol $\left(2 \mu \mathrm{g} \mathrm{L}^{-1}\right)$ and metropolol acid $\left(2 \mu \mathrm{g} \mathrm{L}^{-1}\right)$ from HWW. They proposed two different configurations: biological process $+\mathrm{AOP}$ and AOP + biological process. The removal rates of metropolol and metropolol acid were $85.7 \%$ and $98.5 \%$, respectively, during the sequence biological process + AOP. However, the degradation efficiencies increased when AOP + biological process was carried out. Specifically, removal percentages of $85.6 \%$ and $99.5 \%$ were achieved for metropolol and metropolol acid, respectively. Furthermore, the intermediate compounds were removed up to $85 \%$. This reveals that the sequence AOP + biological process improves the removal of metoprolol and metoprolol acid from HWW.

\subsection{Electrochemical Advanced Oxidation Processes (EAOPs)}

AOPs based on electrochemical technology have been recently applied to the degradation of PhCs in hospital wastewater [74-77]. These processes are commonly called Electrochemical Advanced Oxidation Processes (EAOPs) and, promote the generation of large amounts of highly reactive species from the in-situ oxidation and reduction reactions induced in the effluents without the addition of chemicals for the removal of organics [78]. The selection of appropriate electrode materials and reactor design are critical for developing highly efficient EAOPs $[79,80]$. Likewise, the current density is the most influential operating parameter for the development and scale-up of EAOPs. Table 4 summarizes the most relevant EAOPs reported in the literature until 2021 for the degradation of PhCs in HWW. 
Table 4. EAOPS for the removal of PhCs in HWW.

\begin{tabular}{|c|c|c|c|c|c|c|}
\hline Effluent & Technology & $\begin{array}{c}\text { Operation } \\
\text { Parameters }\end{array}$ & Target Drug & Concentration & $\%$ Elimination & Ref. \\
\hline HWW & Electrooxidation & 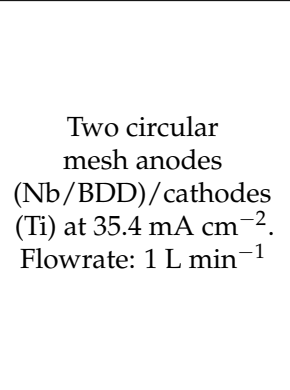 & $\begin{array}{c}\text { Caffeine } \\
\text { Dihydrocabamazenine } \\
\text { Desvenlafaxine } \\
\text { Sulfamethoxazole } \\
\text { Venlafaxine } \\
\text { 2-Hydroxy Ibuprofen } \\
\text { Carbamazepine } \\
\text { 4-Hydroxy Diclofenac } \\
\text { Diclofenac } \\
\text { Ibuprofen } \\
\text { Clarithromycin }\end{array}$ & $\begin{array}{l}93 \mu \mathrm{g} \mathrm{L}^{-1} \\
4.9 \mu \mathrm{g} \mathrm{L}^{-1} \\
8 \mu \mathrm{g} \mathrm{L}^{-1} \\
3 \mu \mathrm{g} \mathrm{L}^{-1} \\
3.87 \mu \mathrm{g} \mathrm{L}^{-1} \\
69 \mu \mathrm{g} \mathrm{L}^{-1} \\
0.62 \mu \mathrm{g} \mathrm{L}^{-1} \\
0.13 \mu \mathrm{g} \mathrm{L}^{-1} \\
0.16 \mu \mathrm{g} \mathrm{L}^{-1} \\
20 \mu \mathrm{g} \mathrm{L}^{-1} \\
0.06 \mu \mathrm{g} \mathrm{L}^{-1}\end{array}$ & $>50(120 \mathrm{~min})$ & [21] \\
\hline HWW & Electrooxidation & $\begin{array}{c}\text { Flow-through } \\
\text { electrochemical cell. } \\
\text { BDD electrodes layer } \\
\text { at } 0.9 \text { and } 3.1 \mathrm{~A} \text { and } \\
50^{\circ} \mathrm{C}\end{array}$ & $\begin{array}{c}\text { Iopromide } \\
\text { 17-alpha- } \\
\text { ethinylestradiol } \\
\text { Sulfamethoma-zole } \\
\text { Diclofenac }\end{array}$ & $\begin{array}{c}0.5 \text { or } \\
10 \mathrm{mg} \mathrm{L}^{-1}\end{array}$ & $\begin{array}{c}0.5 \mathrm{mg} \mathrm{L}^{-1}-0.9 \mathrm{~A}: \\
\sim 32 / 95 / 99 / 87 \\
\quad(180 \mathrm{~min}) \\
0.5 \mathrm{mg} \mathrm{L}^{-1}-3.1 \mathrm{~A}: \\
\sim 78 / 100 / 100 / 100 \\
\quad(180 \mathrm{~min}) \\
10 \mathrm{mg} \mathrm{L}^{-1}-3.1 \mathrm{~A}: \\
\sim 100 / 100 / 100 / 100 \\
\quad(540 \mathrm{~min})\end{array}$ & {$[74]$} \\
\hline Urine & Electrooxidation & $\begin{array}{l}\text { BDD anodes with } \\
\text { boron content of } 100, \\
200,1300,2500 \text { and } \\
8000 \mathrm{ppm} \text { and } \\
\text { stainless steel } \\
\text { (cathode) } \\
\text { at } 30.00 \mathrm{~mA} \mathrm{~cm}^{-2}\end{array}$ & Penicillin G & $50 \mathrm{mg} \mathrm{L}^{-1}$ & $\begin{array}{c}\text { BDD100/98.03 at } \\
6.4 \mathrm{Ah} \mathrm{dm}-3 \\
\text { BDD200/100.00 at } \\
6.4 \mathrm{Ah} \mathrm{dm}^{-3} \\
\text { BDD1300/94.50 } \\
\text { at } 6.4 \mathrm{Ah} \mathrm{dm} \mathrm{dm}^{-3} \\
\text { BDD2500/89.90 at } \\
6.4 \mathrm{Ah} \mathrm{dm} \mathrm{dm}^{-3} \\
\text { BDD8000/94.29 at } \\
6.4 \mathrm{Ah} \mathrm{dm}^{-3}\end{array}$ & {$[75]$} \\
\hline Urine & Electrooxidation & $\begin{array}{c}\text { Single compartment } \\
\text { electrochemical cell. } \\
\text { BDD anode at } 10 \text { and } \\
100 \mathrm{~mA} \mathrm{~cm}^{-2} \\
\text { MMO anode at } 10 \\
\text { and } 100 \mathrm{~mA} \mathrm{~cm}^{-2}\end{array}$ & Penicillin G & $100 \mathrm{mg} \mathrm{L}^{-1}$ & $\begin{array}{c}\text { BDD: } 100.00 \\
\left(10 \mathrm{~mA} \mathrm{~cm}^{-2} ;\right. \\
\left.2.60 \mathrm{Ah} \mathrm{dm}^{-3}\right) / 100.00 \\
\left(100 \mathrm{~mA} \mathrm{~cm}^{-2} ;\right. \\
\left.1.54 \mathrm{Ah} \mathrm{dm}^{-3}\right) \\
\text { MMO:100.00 } \\
\left(10 \mathrm{~mA} \mathrm{~cm}{ }^{-2} ;\right. \\
\left.12.30 \mathrm{Ah} \mathrm{dm}^{-3}\right) \\
/ 100.00\left(100 \mathrm{~mA} \mathrm{~cm}^{-2} ;\right. \\
\left.5.61 \mathrm{Ah} \mathrm{dm}^{-3}\right)\end{array}$ & [76] \\
\hline Urine & Electrooxidation & $\begin{array}{c}\text { Pair of } \\
\text { platinum-based } \\
\text { iridium oxide } \\
\text { composite electrodes } \\
\text { at } 1 \text { A. The urine was } \\
\text { diluted 2-fold, 4-fold } \\
\text { and 8-fold. }\end{array}$ & Methotrexate & $880.2 \mu \mathrm{M}$ & $\begin{array}{c}\text { 2-fold/98.66 (4 h) } \\
\text { 4-fold/99.98 (4 h) } \\
\text { 8-fold/100.00 (4 h) }\end{array}$ & [77] \\
\hline Urine & Electrooxidation & $\begin{array}{c}\text { Anodic } \\
\text { oxidation- } \mathrm{H}_{2} \mathrm{O}_{2} . \\
\text { Three types of anodes. } \\
\text { BDD, Pt and } \mathrm{IrO} \mathrm{O}_{2} . \\
\text { Cathode: } \\
\text { carbon-PTFE air } \\
\text { diffusion electrode, } \\
\mathrm{pH}=3 \text { at } \\
33.3 \mathrm{~mA} \mathrm{~cm}-2\end{array}$ & Captopril & $0.23 \mathrm{mM}$ & $\begin{array}{c}\text { BDD anode: } 100.00 \\
\text { (60 min) } \\
\text { Pt anode: } \\
100.00(60 \mathrm{~min}) \\
\mathrm{IrO}_{2} \text { anode: } \\
87.00(60 \mathrm{~min})\end{array}$ & [80] \\
\hline
\end{tabular}


Table 4. Cont.

\begin{tabular}{|c|c|c|c|c|c|c|}
\hline Effluent & Technology & $\begin{array}{l}\text { Operation } \\
\text { Parameters }\end{array}$ & Target Drug & Concentration & $\%$ Elimination & Ref. \\
\hline Urine & $\begin{array}{c}\text { Solar } \\
\text { Photo } \\
\text { Electro-Fenton }\end{array}$ & $\begin{array}{c}\text { A solar planar } \\
\text { pre-pilot flow plant. } \\
\text { Anode: Pt plate. } \\
\text { Cathode: } \\
\text { carbon-PTFE air } \\
\text { diffusion electrode. } \\
\text { Flow rate: } \\
180 \mathrm{~L} \mathrm{~h}^{-1} \text { and } \\
0.5 \mathrm{mM} \mathrm{Fe}^{2+} \text { at } \\
50 \mathrm{~mA} \mathrm{~cm}^{-2} \text { and } \mathrm{pH} \\
3 \text { and } 35^{\circ} \mathrm{C} \\
\text { Three synthetic } \\
\text { urine solutions } \\
\text { Urine } 1: 13.9 \text { mM urea } \\
+0.073 \mathrm{mM} \text { uric acid }+ \\
0.367 \mathrm{mM} \text { creatinine } \\
\text { Urine } 2: 27.8 \text { mM urea } \\
+0.146 \mathrm{mM} \text { uric acid }+ \\
0.734 \mathrm{mM} \text { creatinine } \\
\text { Urine } 3: 55.6 \text { mM urea } \\
+0.292 \mathrm{mM} \text { uric acid }+ \\
1.470 \mathrm{mM} \text { creatinine }\end{array}$ & Captopril & $0.23 \mathrm{mM}$ & $\begin{array}{l}\text { Urine } 1: \\
100(15 \mathrm{~min}) \\
\text { Urine } 2: \\
100(20 \mathrm{~min}) \\
\text { Urine } 3: \\
100(30 \mathrm{~min})\end{array}$ & [80] \\
\hline Urine & Electrooxidation & $\begin{array}{l}\text { One-compartment } \\
\text { filter-press flow cell. } \\
\text { Flow rate: } \\
460 \mathrm{~mL} \mathrm{~min}^{-1} . \\
\mathrm{Ti} / \mathrm{Ru}_{0.3} \mathrm{Ti}_{0.7} \mathrm{O}_{2} \mathrm{DSA}{ }^{\circledR} \\
\text { at } 10,20,30 \text { and } \\
40 \mathrm{~mA} \mathrm{~cm}^{-2}\end{array}$ & Tetracycline & $200 \mathrm{mg} \mathrm{L}^{-1}$ & $\begin{array}{c}10 \mathrm{~mA} \mathrm{~cm}^{-2}: \\
\sim 52.00(3 \mathrm{~h}) \\
20 \mathrm{~mA} \mathrm{~cm}^{-2}: \\
\sim 83.00(3 \mathrm{~h}) \\
30 \mathrm{~mA} \mathrm{~cm}^{-2}: \\
\sim 99.00(3 \mathrm{~h}) \\
40 \mathrm{~mA} \mathrm{~cm}^{-2}: \\
\sim 100.00(3 \mathrm{~h})\end{array}$ & [81] \\
\hline Urine & Electrooxidation & $\begin{array}{c}\mathrm{MMO}-\mathrm{Ti} / \mathrm{RuO}_{2}-\mathrm{IrO}_{2} \\
\text { anode and zirconium } \\
\text { spiral (cathode) at } \\
4.0 \mathrm{~mA} \mathrm{~cm}^{-2}\end{array}$ & Cephalexin & $86.0 \mu \mathrm{M}$ & $\begin{array}{l}\sim 100.00(2 \mathrm{~h} \text { or } \\
\left.0.43 \mathrm{Ah} \mathrm{dm}^{-3}\right)\end{array}$ & [82] \\
\hline Urine & Electrooxidation & $\begin{array}{c}\text { BDD with } 500 \text { ppm of } \\
\text { boron (Diacell cell) at } \\
20,50 \text { and } \\
100 \mathrm{~mA} \mathrm{~cm}^{-2} \text {. Flow } \\
\text { rate: } 6.67 \mathrm{~mL} \mathrm{~s}^{-1} \text {. } \\
\text { Urine in methanol. }\end{array}$ & $17-\beta$ Estradiol & $10 \mathrm{mg} \mathrm{L}^{-1}$ & $\begin{array}{c}20 \mathrm{~mA} \mathrm{~cm}^{-2}: \\
100 \sim 7 \mathrm{Ah} \mathrm{dm}^{-3} \\
50 \mathrm{~mA} \mathrm{~cm}^{-2}: \\
100 \sim 13 \mathrm{Ah} \mathrm{dm}^{-3} \\
100 \mathrm{~mA} \mathrm{~cm}^{-2}: \\
100 \sim 15 \mathrm{Ah} \mathrm{dm}^{-3}\end{array}$ & [83] \\
\hline Urine & Electrooxidation & $\begin{array}{l}\text { Single compartment } \\
\text { electrochemical cell. } \\
\text { BDD anode with } \\
\text { boron content of } \\
500 \text { ppm at } 100 \text { and } \\
1000 \mathrm{~A} \mathrm{~m}^{-2}\end{array}$ & $\begin{array}{l}\text { Ibuprofen } \\
\text { Cloxacillin }\end{array}$ & $\begin{array}{l}10 \mathrm{mg} \mathrm{L}^{-1} \\
1 \mathrm{mg} \mathrm{L}^{-1}\end{array}$ & $\begin{array}{c}100 \mathrm{~A} \mathrm{~m}^{-2}: \text { Ibuprofen/ } \\
100 \sim 32 \mathrm{Ah} \mathrm{dm}^{-3} \\
\text { Cloxacillin/100 } \\
18 \mathrm{Ah} \mathrm{dm}^{-3} \\
1000 \mathrm{~A} \mathrm{~m}^{-2}: \text { Ibuprofen/ } \\
100 \sim 28 \mathrm{Ah} \mathrm{dm}^{-3} \\
\text { Cloxacillin/ } \\
100 \sim 13 \mathrm{Ah} \mathrm{dm}^{-3}\end{array}$ & [84] \\
\hline HWW & Electrooxidation & $\begin{array}{c}\mathrm{Ti} / \mathrm{IrO}_{2} \text { rectangular } \\
\text { (anode) and } \\
\text { zirconium spiral } \\
\text { (cathode) } \mathrm{pH}=6.5 \text { at } \\
5 \mathrm{~mA} \mathrm{~cm}{ }^{-2}\end{array}$ & Cephalexin & $40 \mu \mathrm{M}$ & $\sim 60(30 \mathrm{~min})$ & [85] \\
\hline Urine & Electrooxidation & $\begin{array}{c}\text { Undivided cell } \\
\text { equipped with a } \\
\mathrm{Ti} / \mathrm{IrO}_{2} \text { anode and a } \\
\text { zirconium spiral } \\
\text { cathode. } \mathrm{pH}=6.0 \text { and } \\
5 \mathrm{~mA} \mathrm{~cm}{ }^{-2}\end{array}$ & $\begin{array}{l}\text { Naproxen } \\
\text { Diclofenac }\end{array}$ & $\begin{array}{l}40 \mu \mathrm{M} \\
40 \mu \mathrm{M}\end{array}$ & $\begin{array}{l}20(60 \mathrm{~min}) \\
30(60 \mathrm{~min})\end{array}$ & [86] \\
\hline
\end{tabular}


Table 4. Cont.

\begin{tabular}{|c|c|c|c|c|c|c|}
\hline Effluent & Technology & $\begin{array}{l}\text { Operation } \\
\text { Parameters }\end{array}$ & Target Drug & Concentration & $\%$ Elimination & Ref. \\
\hline Urine & Electrooxidation & $\begin{array}{l}\mathrm{MMO}-\mathrm{Ti} / \mathrm{IrO}_{2} \text { anode } \\
\text { and Titanium cathode } \\
\text { at } 6.53 \mathrm{~mA} \mathrm{~cm}{ }^{-2}\end{array}$ & Norfloxacin & $125.0 \mu \mathrm{M}$ & $\sim 65(180 \mathrm{~min})$ & [87] \\
\hline Urine & Electrooxidation & $\begin{array}{l}\text { Undivided cell. Pt } \\
\text { sheet was used as } \\
\text { anode and a glassy } \\
\text { carbon was used as } \\
\text { cathode. Current } \\
\text { density range: } \\
0.5-150.0 \mathrm{~mA} \mathrm{~cm}^{-2}\end{array}$ & Cefazolin & $100.0 \mu \mathrm{M}$ & $\begin{array}{c}0.5 \mathrm{~mA} \mathrm{~cm}^{-2}: \\
\sim 100\left(500 \mathrm{~min}^{-}\right) \\
5.0 \mathrm{~mA} \mathrm{~cm}^{-2}: \\
\sim 100\left(160 \mathrm{~min}^{-}\right. \\
50.0 \mathrm{~mA} \mathrm{~cm}^{-2}: \\
\sim 100\left(40 \mathrm{~min}^{-}\right. \\
150.0 \mathrm{~mA} \mathrm{~cm} \\
\sim 100(10 \mathrm{~min})\end{array}$ & [88] \\
\hline Urine & Electrooxidation & $\begin{array}{l}\text { A platinum net was } \\
\text { used as anode and } \\
\text { reticulated nickel } \\
\text { foam electrode was } \\
\text { used as cathode and. } \\
\text { V: } 1 \mathrm{~V}\end{array}$ & Iomeprol & $0.1 \mathrm{mM}$ & $100(120 \mathrm{~min})$ & [89] \\
\hline Urine & Electrooxidation & $\begin{array}{l}\text { Single compartment } \\
\text { electrochemical cell. } \\
\text { BDD anode and } \\
\text { stainless steel } \\
\text { (cathode) at } 1.25,2.5 \\
\text { and } 5 \mathrm{~mA} \mathrm{~cm}^{-2} \text {. } \\
{\mathrm{MMO}-\mathrm{RuO}_{2} \text { anode }} \text { and stainless steel } \\
\text { (cathode) at } 1.25,2.5 \\
\text { and } 5 \mathrm{~mA} \mathrm{~cm} \mathrm{~cm}^{-2} \text {. }\end{array}$ & Chloramphenicol & $100 \mathrm{mg} \mathrm{L}^{-1}$ & $\begin{array}{c}\text { BDD at } \\
1.25 \mathrm{~mA} \mathrm{~cm}^{-2} / 100 \\
\left(8 \mathrm{Ah} \mathrm{dm}^{-3}\right) \\
\text { BDD at } 2.5 \mathrm{~mA} \mathrm{~cm}^{-2} / 100 \\
\left(8 \mathrm{Ah} \mathrm{dm}^{-3}\right) \\
\text { BDD at } 5 \mathrm{~mA} \mathrm{~cm}^{-2} / \sim 90 \\
\left(6.46 \mathrm{Ah} \mathrm{dm}^{-3}\right) \\
\mathrm{MMO} \mathrm{at} \\
1.25 \mathrm{~mA} \mathrm{~cm}^{-2} / 36.86 \\
\left(8 \mathrm{Ah} \mathrm{dm}^{-3}\right) \\
\mathrm{MMO} \text { at }^{-3} \\
2.5 \mathrm{~mA} \mathrm{~cm}^{-2} / 25.88 \\
\left(8 \mathrm{Ah} \mathrm{dm}^{-3}\right) \\
\mathrm{MMO} \text { at }^{-2} \\
5 \mathrm{~mA} \mathrm{~cm}^{-2} / 16.26 \\
\left(6.46 \mathrm{Ah} \mathrm{dm}^{-3}\right)\end{array}$ & [90] \\
\hline HWW & $\begin{array}{l}\text { MBR- } \\
\text { Electrooxidation }\end{array}$ & $\begin{array}{c}\text { Submerged } \\
\text { membrane bioreactor } \\
(\mathrm{MBR}) \text { in } \\
\text { continuous mode. } \\
\text { Electrooxidation } \\
\text { reactor in } \\
\text { discontinuous mode. } \\
\mathrm{Nb} / \mathrm{BDD} \text { anode } \\
\text { at } 0.5 \mathrm{~A} \text {. }\end{array}$ & $\begin{array}{l}\text { Carbamazepine } \\
\text { Ibuprofen } \\
\text { Estradiol } \\
\text { Venlafaxine }\end{array}$ & $\begin{array}{l}10 \mu \mathrm{g} \mathrm{L}^{-1} \\
10 \mu \mathrm{g} \mathrm{L}^{-1} \\
10 \mu \mathrm{g} \mathrm{L}^{-1} \\
0.2 \mu \mathrm{g} \mathrm{L}^{-1}\end{array}$ & $\begin{array}{c}\text { MBR-EO } \\
\sim 97(40 \mathrm{~min})\end{array}$ & [91] \\
\hline HWW/urine & Electro-Fenton & $\begin{array}{c}\text { BDD anode, } \\
\text { 3D-Carbon-felt } \\
\text { (cathode), } 0.1 \mathrm{mM} \\
\mathrm{Fe}^{2+} \mathrm{pH}: 3 \text { at } \\
4.17 \mathrm{~mA} \mathrm{~cm}{ }^{-2}\end{array}$ & Piroxicam & $25.6 \mathrm{mg} \mathrm{L}^{-1}$ & 100 (120 min) & [92] \\
\hline HWW & Electro-Fenton & $\begin{array}{c}\text { Two iron plate } \\
\text { electrodes. } 2.75 \mathrm{pH} \\
\text { solution, } 122.5 \mu \mathrm{L} \mathrm{L}^{-1} \\
\mathrm{H}_{2} \mathrm{O}_{2} \text { and } 8 \mathrm{~mA} \mathrm{~cm}{ }^{-2}\end{array}$ & Acetaminophen & $1.35 \mathrm{mg} \mathrm{L}^{-1}$ & $100(10 \mathrm{~min})$ & [93] \\
\hline
\end{tabular}


Table 4. Cont.

\begin{tabular}{|c|c|c|c|c|c|c|}
\hline Effluent & Technology & $\begin{array}{l}\text { Operation } \\
\text { Parameters }\end{array}$ & Target Drug & Concentration & $\%$ Elimination & Ref. \\
\hline Urine & Electro-Fenton & $\begin{array}{c}\text { Microfluidic } \\
\text { Flow-Through reactor. } \\
\text { Pressurized system. } \\
\text { 3D-MMO-IrO } \mathrm{Ta}_{2} \mathrm{O}_{5} \\
\text { anode and modified } \\
\text { 3D-titanium mesh } \\
\text { with } \mathrm{CB} / \mathrm{PTFE} \\
\text { cathode, pH } 3, \\
5 \mathrm{~mA} \mathrm{~cm}-2 \text {, and } \\
10.8 \mathrm{~g}^{-} \text {goethite } \\
\text { (heterogeneous } \\
\text { catalyst). } \\
\text { Gauge pressure range: } \\
0,1,2 \text { and } 3 \text { bar }\end{array}$ & Meropenem & $50 \mathrm{mg} \mathrm{L}^{-1}$ & $\begin{array}{c}0 \text { bar: } 80.60 \\
\left(0.8 \mathrm{Ah} \mathrm{dm} \mathrm{dm}^{-3}\right) \\
1 \text { bar: } 89.03 \\
\left(0.8 \mathrm{Ah} \mathrm{dm}^{-3}\right) \\
2 \text { bar: } 91.60 \\
\left(0.8 \mathrm{Ah} \mathrm{dm} \mathrm{dm}^{-3}\right) \\
3 \text { bar: } 94.64 \\
\left(0.8 \mathrm{Ah} \mathrm{dm}^{-3}\right)\end{array}$ & [94] \\
\hline Urine & $\begin{array}{c}\text { Electrooxidation } \\
\text { and } \\
\text { photo-electro } \\
\text { oxidation }\end{array}$ & $\begin{array}{c}\text { Microwave-made } \\
{\mathrm{MMO}-\mathrm{Ti} / \mathrm{RuO}_{2} \mathrm{IrO}}_{2} \\
\text { anode and stainless } \\
\text { steel (cathode). BDD } \\
\text { anode with a boron } \\
\text { content of } 200 \mathrm{ppm} \\
\text { and stainless steel } \\
\text { (cathode). Current } \\
\text { density: } 30 \mathrm{~mA} \mathrm{~cm}{ }^{-2} \text {. } \\
\text { UVC lamp } 9 \mathrm{~W} \mathrm{in} \\
\text { photo- } \\
\text { electrooxidation. }\end{array}$ & Penicillin G & $50 \mathrm{mg} \mathrm{L}^{-1}$ & $\begin{array}{c}\text { EO-MMO: } \\
\sim 94.0(8 \mathrm{~h}) \\
\text { EO-BDD: } \\
\sim 89.0(8 \mathrm{~h}) \\
\text { PhEO-MMO: } \sim 100.0(8 \mathrm{~h}) \\
\text { PhEO-BDD: } \sim 98.0(8 \mathrm{~h})\end{array}$ & [95] \\
\hline Urine & $\begin{array}{l}\text { Electro-Fenton or } \\
\text { photo } \\
\text { Electro-Fenton }\end{array}$ & $\begin{array}{l}\text { Two different anode: } \\
200 \text { ppm BDD and } \\
\text { a MMO- } \\
\mathrm{Ti}^{-} \mathrm{Ru}_{0.5} \mathrm{Ir}_{0.5} \mathrm{O}_{2} . \\
\text { Cathode: modified } \\
\text { carbon felt. } 120 \mathrm{~mA} \text {. } \\
0.5 \mathrm{mM} \text { of Fe } \mathrm{Fe}^{2+}, \mathrm{pH} 3 \\
\text { and a } 9 \mathrm{~W} \mathrm{UVC} \text { lamp } \\
\text { for the PhEF tests }\end{array}$ & Penicillin G & $50 \mathrm{mg} \mathrm{L}^{-1}$ & $\begin{array}{c}\text { EF-MMO: } \\
\text { 99.0 (8 h) } \\
\text { EF-BDD: } \\
\text { 98.4 (8 h) } \\
\text { PhEF-MMO: } 100.0(8 \mathrm{~h}) \\
\text { PhEF-BDD: } \\
99.6(8 \mathrm{~h})\end{array}$ & [96] \\
\hline Urine & $\begin{array}{c}\text { Electrooxidation } \\
\text { and } \\
\text { photo-electro } \\
\text { oxidation }\end{array}$ & $\begin{array}{c}\text { Two experimental } \\
\text { configurations: } \\
\text { Conventional } \\
\text { stirred-tank } \\
\text { Anode: } 2 \mathrm{D}-\mathrm{MMO}- \\
\mathrm{Ti}^{\mathrm{T}} \mathrm{RuO}_{2} \mathrm{IrO}_{2} \text { plate } \\
\mathrm{Cathode:} \\
\text { stainless steel } \\
\text { Microfluidic } \\
\text { Flow-Through } \\
\text { Anode: } 3 \mathrm{D}-\mathrm{MMO}- \\
\mathrm{Ti} / \mathrm{RuO}_{2} \mathrm{IrO} \\
\text { foam } \\
\mathrm{Cathode} \\
\text { stainless steel } \\
\text { Current density: } \\
30 \mathrm{~mA} \mathrm{~cm}{ }^{-2} \text {. UVC } \\
\text { lamp } 9 \mathrm{~W} \text { in photo- } \\
\text { electrooxidation. }\end{array}$ & $\begin{array}{c}\text { Penicillin G } \\
\text { Meropenem } \\
\text { Chloramphenicol }\end{array}$ & $\begin{array}{l}50 \mathrm{mg} \mathrm{L}^{-1} \\
50 \mathrm{mg} \mathrm{L}^{-1} \\
50 \mathrm{mg} \mathrm{L}^{-1}\end{array}$ & $\begin{array}{c}\text { Conventional stirred-tank: } \\
\text { EO: >70\% }\left(6.4 \mathrm{Ah} \mathrm{dm}^{-3}\right) \\
\text { PhEO: } 82 \%\left(6.4 \mathrm{Ah} \mathrm{dm}^{-3}\right) \\
\text { Microfluidic } \\
\text { Flow-Through } \\
\text { EO > 70\% } \\
\left(6.4 \mathrm{Ah} \mathrm{dm} \mathrm{dm}^{-3}\right) \\
\text { PhEO: } 100 \% \\
\left(6.4 \mathrm{Ah} \mathrm{dm} \mathrm{dm}^{-3}\right)\end{array}$ & [97] \\
\hline
\end{tabular}

Electrochemical oxidation is the most widely used EAOP for the removal of organic pollutants in water matrices [81-83]. Specifically, this process consists of the abatement of organics in an electrolytic cell by different mechanisms: (i) direct electron transfer to the anode and (ii) indirect or mediated oxidation by highly reactive species formed from water discharge at the anode surface [84]. Figure 6 shows the main mechanisms of the process related to oxidants production and activation [98]. 


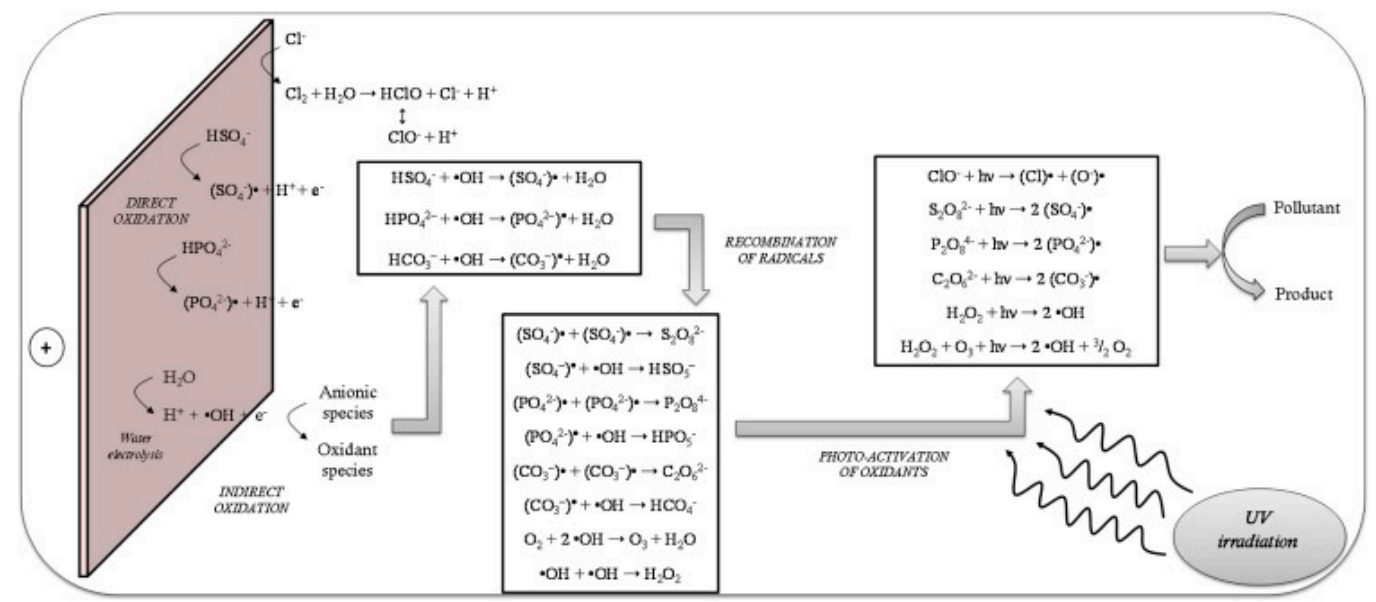

Figure 6. Mechanisms expected for the photo-electrolytic reclamation of secondarily treated wastewater. Reprinted with permission from ref [98]. Copyright 2016 Elsevier.

The anode materials used for the development of this process can be classified as active and non-active anodes. The first ones favor the chemisorption of in situ electrogenerated free radicals on the anode surface whereas non-active anodes promote the physisorption of these species [99]. Materials based on $\mathrm{Pt}, \mathrm{IrO}_{2}$ and $\mathrm{RuO}_{2}$ are examples of active anodes, and diamond-based coatings, $\mathrm{SnO}_{2}$, or $\mathrm{PbO}_{2}$ are considered as non-active anodes [100]. The application of electrooxidation to the treatment of HWW polluted with cephalexin was studied by Serna-Galvis et al. [85] using a $\mathrm{Ti} / \mathrm{IrO}_{2}$ anode. The antibiotic $(40 \mu \mathrm{M})$ removal rate was approximately $60 \%$ after $30 \mathrm{~min}$, applying a current density of $5 \mathrm{~mA} \mathrm{~cm}$ ch $^{-2}$ at $\mathrm{pH}$ 6.5. The presence of significant amounts of chloride ions in the effluent promoted the electrochemical production of free chlorine by anodic oxidation, which improved the degradation of the antibiotic by an indirect oxidation mechanism. The same experimental set-up and electrodes materials ( $\mathrm{Ti} / \mathrm{IrO}_{2}$ anode and zirconium spiral cathode) were used by [86]. In this case, they studied the simultaneous degradation of diclofenac $(40 \mu \mathrm{M})$ and naproxen $(40 \mu \mathrm{M})$ in urine at $5 \mathrm{~mA} \mathrm{~cm}^{-2}$ and $\mathrm{pH}$ 6.0. Results showed elimination rates of $30 \%$ for diclofenac and $20 \%$ for naproxen in $30 \mathrm{~min}$ of electrolysis.

$\mathrm{A} \mathrm{Ti} / \mathrm{IrO}_{2}$ anode (Figure 7) was also tested by Jojoa-sierra et al. [87] for the removal of $125 \mu \mathrm{M}$ norfloxacin in urine applying $6.53 \mathrm{~mA} \mathrm{~cm}^{-2}$. An antibiotic removal percentage of around $65 \%$ was attained at 180 min since the oxidation of urea competes with the degradation of norfloxacin during the electrolysis of urine.

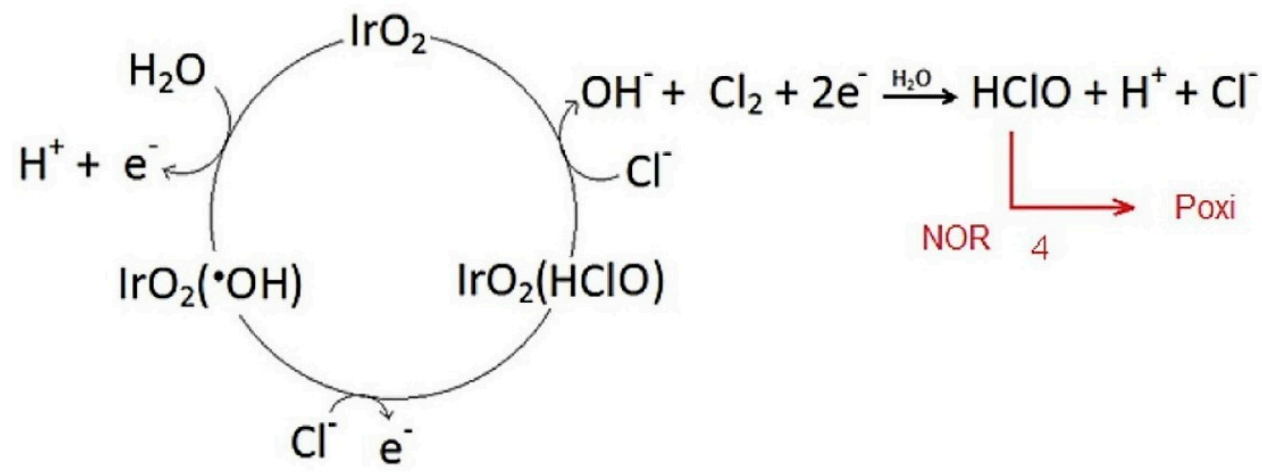

Figure 7. Main electrochemical degradation pathway of norfloxacin in presence of chloride ions. Reprinted with permission from ref. [87]. Copyright 2017 Elsevier.

Sordello et al. [88] evaluated the feasibility of the electrooxidation process for the removal of Cefazolin $(100 \mu \mathrm{M})$ from urine using a platinum sheet anode and a glassy carbon cathode. The range of current densities was $0.5-150.0 \mathrm{~mA} \mathrm{~cm}^{-2}$. They concluded 
that Cefazolin can be degraded at current densities from 0.5, 5.0, 50.0 and $150.0 \mathrm{~mA} \mathrm{~cm}^{-2}$ at approximate electrolysis times of 500, 160, 40 and $10 \mathrm{~min}$, respectively. Zwiener et al. [89] used a platinum net as anode and used a reticulated nickel foam electrode as a cathode to remove $0.1 \mathrm{mM}$ of iomeprol (iodinated contrast media) in urine. The voltage applied during electrooxidation was $1 \mathrm{~V}$. Complete removal of iomeprol was achieved after $120 \mathrm{~min}$ of electrolysis.

On the other hand, the degradation of a mixture of PhCs (analgesics, antibiotics, antihypertensive, caffeine) in HWW with concentrations ranging from $0.16 \mu \mathrm{g} \mathrm{L}^{-1}$ to $93 \mu \mathrm{g} \mathrm{L}{ }^{-1}$ by electrochemical oxidation was reported by Ouarda et al. [21]. Boron doped diamond was used as an anode, Ti as cathode and the applied current densities between both electrodes were within the range $4.42-35.4 \mathrm{~mA} \mathrm{~cm}^{-2}$. Results showed that pharmaceutical abatement rates were greater than $50 \%$ after 120 min of electrolysis when applying $35.4 \mathrm{~mA} \mathrm{~cm}^{-2}$. More recently, Herraiz-Carboné et al. [90] compared the use of active and non-active anodes for the removal of $100 \mathrm{mg} \mathrm{dm}^{-3}$ chloramphenicol in urine. They concluded that it was possible to attain a complete antibiotic removal when working with BDD anodes for all the current densities tested $\left(1.25-5 \mathrm{~mA} \mathrm{~cm}^{-2}\right)$ whereas the use of anodes based on mixed metal oxides (MMO) led to removal percentages of around $25 \%$ under the same operating conditions (Figure 8). Free and combined chlorine species were generated during the treatment of urine from the oxidation of chlorides which contributed to the degradation of antibiotics with both anodes. Nonetheless, the use of BDD anodes also promoted the electrochemical generation of peroxocompounds, such as persulfate or peroxodiphosphate from the oxidation of other ions contained in urine, favoring antibiotic removal.

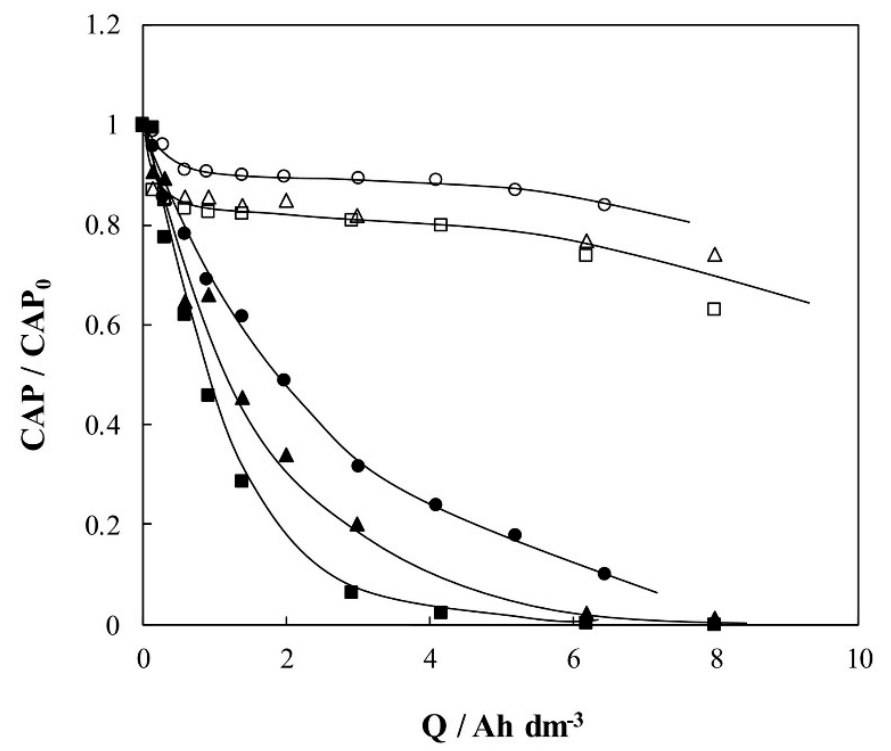

Figure 8. Evolution of chloramphenicol as a function of the applied electric charge during the electrochemical oxidation of $100 \mathrm{mg} \mathrm{dm}^{-3}$ CAP in urine media. Current density: $(\boldsymbol{\square}, \square) 1.25 \mathrm{~mA} \mathrm{~cm}^{-2}$; $(\boldsymbol{\Delta}, \Delta) 2.5 \mathrm{~mA} \mathrm{~cm}^{-2} ;(\bullet, \bigcirc) 5 \mathrm{~mA} \mathrm{~cm}^{-2}$. Anodic material: (black symbols) BDD; (white symbols) MMO. Reprinted with permission from ref [90]. Copyright 2020 Elservier.

To reduce the costs and energy consumption of the electrochemical processes for the removal of $\mathrm{PhCs}$, some authors have evaluated the combination of electrooxidation with biological processes. Ouarda et al. [91] reported the treatment of HWW contaminated with carbamazepine $\left(10 \mu \mathrm{g} \mathrm{L}^{-1}\right)$, ibuprofen $\left(10 \mu \mathrm{g} \mathrm{L}^{-1}\right)$, estradiol $\left(10 \mu \mathrm{g} \mathrm{L}^{-1}\right)$ and venlafaxine $\left(0.2 \mu \mathrm{g} \mathrm{L}^{-1}\right)$ using a membrane bioreactor technology combined with the electrooxidation process. They compared the removal efficiencies of the different PhCs using two treatment configurations: electrooxidation process as pre-treatment and post-treatment. Results showed that the most effective combination was the application of electrooxidation as a 
post-treatment (MBR-EO), achieving removal rates of over $97 \%$ for all $\mathrm{PhCs}$ tested after $40 \mathrm{~min}$, applying a current intensity of $0.5 \mathrm{~A}$ with $\mathrm{Nb} / \mathrm{BDD}$ as electrodes.

Another environmentally friendly EAOP applied to the removal of PhCs in water bodies is electro-Fenton [101]. This process starts with the in situ electrogeneration of hydrogen peroxide $\left(\mathrm{H}_{2} \mathrm{O}_{2}\right)$ in the solution by the reduction of oxygen at the cathode according to Equation (3). Then, hydroxyl radicals are homogeneously produced in the bulk from the reaction between electrogenerated $\mathrm{H}_{2} \mathrm{O}_{2}$ and ferrous ion (catalyst) externally added at low $\mathrm{pH}$ values (Fenton reaction) (Equation (1)). Figure 9 shows the main mechanisms involved in the electro-Fenton process.

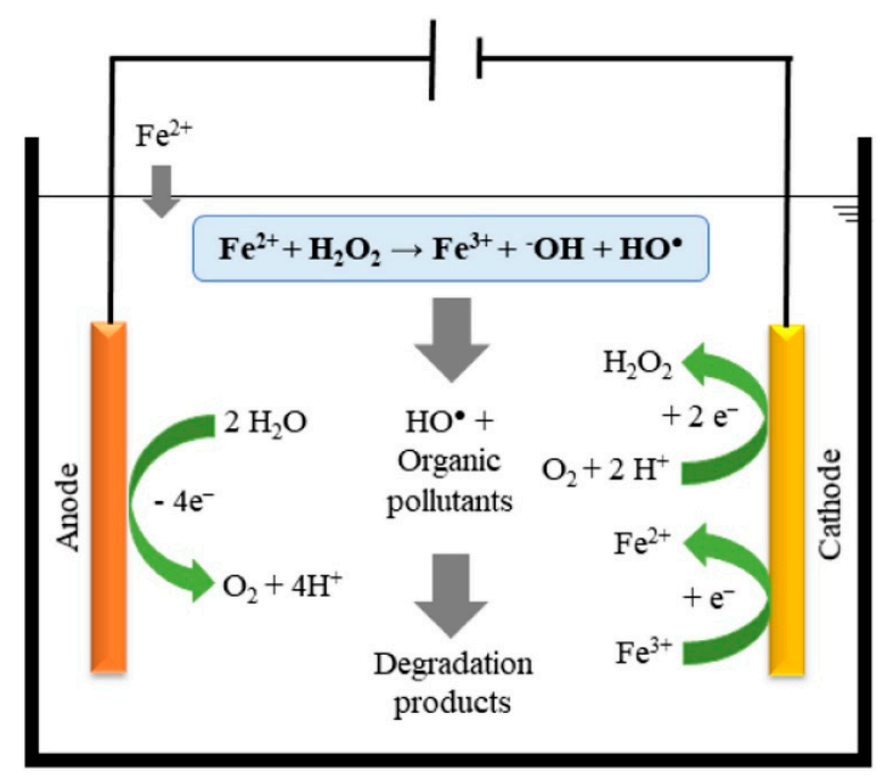

Figure 9. Mechanisms expected in the electro-Fenton process. Reprinted with permission from ref [102]. Copyright 2021 Elsevier.

One of the advantages of the electro-Fenton over classical Fenton process (where the reagents are added chemically) is that the catalyst $\left(\mathrm{Fe}^{2+}\right)$ can be continuously electrogenerated through Equation (4), promoting the catalytic cycle required by the Fenton system. Furthermore, the use of non-active anodes, such as diamond-based coatings during the electro-Fenton process generates an additional source of $\cdot \mathrm{OH}$ which are heterogeneously formed over the anode surface through water oxidation (Equation (5)).

$$
\begin{gathered}
\mathrm{O}_{2}(\mathrm{~g})+2 \mathrm{H}^{+}+2 \mathrm{e}^{-} \rightarrow \mathrm{H}_{2} \mathrm{O}_{2} \\
\mathrm{Fe}^{3+}+\mathrm{e}^{-} \rightarrow \mathrm{Fe}^{2+} \\
\mathrm{H}_{2} \mathrm{O} \rightarrow \cdot \mathrm{OH}+\mathrm{H}^{+}+\mathrm{e}^{-}
\end{gathered}
$$

Feng et al. [92] evaluated the removal of $0.08 \mathrm{mM}$ piroxicam in HWW and urine by electro-Fenton at $\mathrm{pH} 3$, using BDD and 3D-carbon-felt as anode and cathode, respectively. The catalyst concentration employed was $0.1 \mathrm{mM} \mathrm{Fe}^{2+}$ and the current density applied was $4.17 \mathrm{~mA} \mathrm{~cm}^{-2}$. Complete elimination was attained after $120 \mathrm{~min}$ in both effluents, being slower than the results obtained during the treatment of tap water (Figure 10). This can be related to the occurrence of oxidative competitive reactions between the PhC and other organics, such as urea or acetate contained in HWW and urine. On the other hand, the treatment of HWW polluted with $1.35 \mathrm{mg} \mathrm{dm}^{-3}$ acetaminophen by electro-Fenton was reported by Ahmadzadeh et al. [93]. They used two iron plate electrodes at $8 \mathrm{~mA} \mathrm{~cm}^{-2}$, $122.5 \mu \mathrm{L} \mathrm{dm}^{-3} \mathrm{H}_{2} \mathrm{O}_{2}$ and $\mathrm{pH}$ 2.75. The ferrous iron required for carrying out the Fenton reaction was in situ electrogenerated by the electrodissolution of the anode. Results showed that it was possible to attain the complete elimination of acetaminophen after $10 \mathrm{~min}$. 


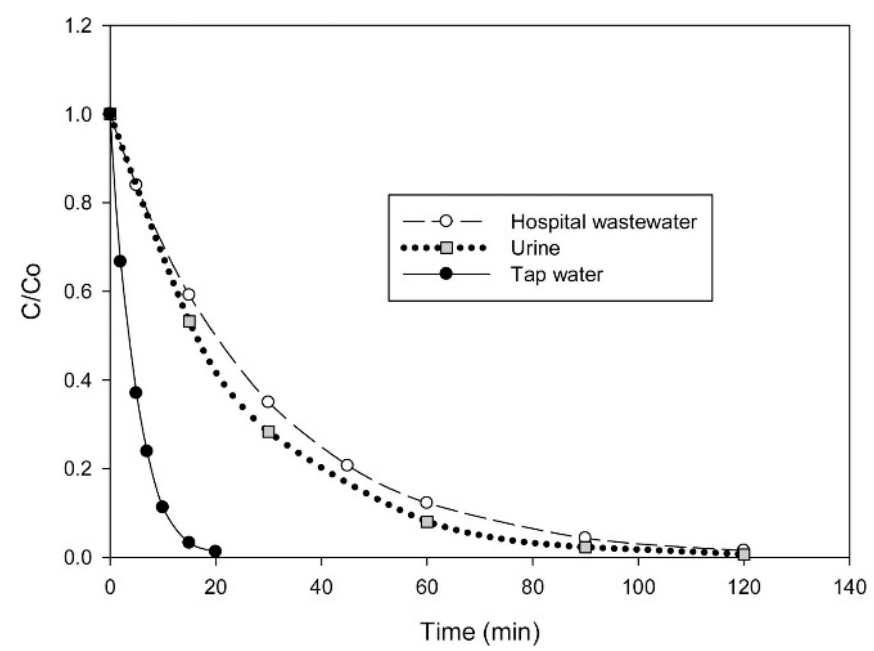

Figure 10. Degradation of piroxicam in different matrices. Experimental conditions: [Piroxicam] = $0.08 \mathrm{mM} ;\left[\mathrm{Na}_{2} \mathrm{SO}_{4}\right]=0.05 \mathrm{M} ;\left[\mathrm{Fe}^{2+}\right]=0.10 \mathrm{mM} ; \mathrm{I}=100 \mathrm{~mA}\left(4.17 \mathrm{~mA} \mathrm{~cm}{ }^{-2}\right) ; \mathrm{V}=0.25 \mathrm{~L} ; \mathrm{pH}=3.0$ and room temperature. Reprinted with permission from ref. [92]. Copyright 2019 Elservier.

One of the main disadvantages of the electro-Fenton process is the low solubility of oxygen in water at atmospheric pressure, which significantly influences the production of hydrogen peroxide at the cathode. To overcome this limitation, Moratalla et al. [94] recently reported the use of a pressurized electrochemical reactor equipped with a jet aerator for the removal of meropenem in urine, demonstrating that the electrochemical generation of hydrogen peroxide can be significantly improved by applying high pressures. Specifically, they evaluated the influence of pressure (gauge pressure range of 0 to 3 bar) on the elimination of $50 \mathrm{mg} \mathrm{dm}^{-3}$ meropenem in urine by the heterogeneous electroFenton process, using a $3 \mathrm{D}-\mathrm{MMO}-\mathrm{IrO}_{2} \mathrm{Ta}_{2} \mathrm{O}_{5}$ mesh anode and a modified 3D-titanium mesh with $\mathrm{CB} / \mathrm{PTFE}$ cathode at $5 \mathrm{~mA} \mathrm{~cm}^{-2}, \mathrm{pH} 3$ and $10.8 \mathrm{~g}$ goethite (heterogeneous catalyst). Results confirmed that the meropenem degradation rate increased with the gauge pressure. The antibiotic removal percentages attained were $80.60,89.03,91.60$ and $94.64 \%$ at gauge pressures of $0,1,2$ and 3 bar, respectively, when passing $0.8 \mathrm{Ah} \mathrm{dm}^{-3}$ at $5 \mathrm{~mA} \mathrm{~cm}^{-2}$.

EAOPs can be enhanced by the irradiation of UV light to promote the photoactivation of electrogenerated oxidants, favoring the production of free radicals that significantly contribute to the degradation of organic pollutants [103]. Specifically, free chlorine (Equation (6)) and sulfate (Equation (2)) radicals can be generated by the photoactivation of electrogenerated hypochlorite and persulphate with UVC light, respectively [104].

$$
\mathrm{ClO}^{-}+\mathrm{h} v \rightarrow \mathrm{Cl}^{\cdot}+\mathrm{O}^{-}
$$

Gonzaga et al. [95] compared the elimination of $50 \mathrm{mg} \mathrm{dm}^{-3}$ penicillin $\mathrm{G}$ in urine matrixes by electrolysis and photoelectrolysis with active anodes (MMO-Ti/ $\left.\mathrm{RuO}_{2} \mathrm{IrO}_{2}\right)$. They used a UVC lamp of $9 \mathrm{~W}$, and a current density applied of $30 \mathrm{~mA} \mathrm{~cm}^{-2}$. Results showed a marked synergistic effect on the degradation of the antibiotic when coupling UVC light to electrolysis, reaching a total removal of the pollutant in $8 \mathrm{~h}$. The degradation of penicillin $\mathrm{G}$ was also studied by Gonzaga et al. [96], comparing the electro-Fenton and photoelectron-Fenton processes under acidic conditions ( $\mathrm{pH} 3$ ). Two different anodes were used (BDD and MMO-Ti/ $\mathrm{Ru}_{0.5} \mathrm{Ir}_{0.5} \mathrm{O}_{2}$ ) and a modified carbon-felt was employed as the cathode. The catalyst concentration was $0.5 \mathrm{mM} \mathrm{Fe}^{2+}$ and the current intensity was $120 \mathrm{~mA}$. They reported that the influence of the anode material is less relevant, although MMO led to faster penicillin $\mathrm{G}$ removal than BDD anode. The antibiotic degradation was enhanced during the photoelectron-Fenton process since the photoactivation of hydrogen peroxide 
by UVC light irradiation can also take place (Equation (7)), increasing the production of free hydroxyl radicals in the effluent.

$$
\mathrm{H}_{2} \mathrm{O}_{2}+\mathrm{h} v \rightarrow 2 \cdot \mathrm{OH}
$$

Finally, Dos Santos et al. [80] evaluated the removal of captopril (0.23 mM) from urine in three different synthetic urine matrices (Urine 1, Urine 2 and Urine 3) by Solar photo Electro-Fenton. In this case, the photolytic action of sunlight (UVA light) is used for enhancing the performance of the electro-Fenton process. The experiments were carried out in a solar pre-pilot flow plant, where the anode was a Pt plate, and the cathode was a carbon-PTFE air diffusion electrode. The initial amount of $\mathrm{Fe}^{2+}$ was $0.5 \mathrm{mM}$ at $\mathrm{pH} 3$ and $50 \mathrm{~mA} \mathrm{~cm}^{-2}$. Each synthetic urine matrix presents other organic compounds in different concentrations: creatinine, urea and uric acid, where Urine 1 is the most dilute and Urine 3 is the most concentrated. Although these organic compounds slow down the process, captopril abatement was achieved at 15, 20 and 30 min during the treatment of urine 1,2 and 3, respectively (Figure 11).

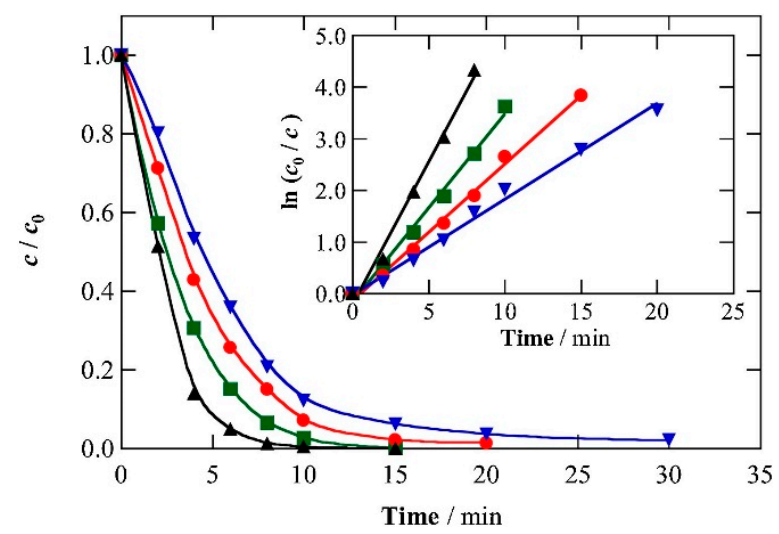

Figure 11. Influence of the aqueous matrix on the normalized captopril concentration decay during the SPEF treatment of $2.5 \mathrm{~L}$ of $0.230 \mathrm{mM}$ drug solutions with $0.50 \mathrm{mM} \mathrm{Fe} \mathrm{m}^{2+}$ at $\mathrm{pH} 3.0$ and $35^{\circ} \mathrm{C}$ using a solar pre-pilot flow plant with a Pt/air-diffusion cell at $j=50 \mathrm{~mA} \mathrm{~cm}^{-2}$ and liquid flow rate of $180 \mathrm{~L} \mathrm{~h}^{-1}$. Matrix: ( $\left.\mathbf{\Delta}\right)$ Urban wastewater, $(\mathbf{\square})$ urine $1(13.9 \mathrm{mM}$ urea $+0.073 \mathrm{mM}$ uric acid + $0.367 \mathrm{mM}$ creatinine $),(\bullet)$ urine $2(27.8 \mathrm{mM}$ urea $+0.146 \mathrm{mM}$ uric acid $+0.734 \mathrm{mM}$ creatinine $)$ and $(\boldsymbol{\nabla})$ urine 3 (55.6 $\mathrm{mM}$ urea $+0.292 \mathrm{mM}$ uric acid $+1.47 \mathrm{mM}$ creatinine). The inset panel shows the kinetic analysis of the above concentration decays assuming a pseudo-first-order reaction. Reprinted with permission from ref. [80]. Copyright 2020 Elsevier.

Another important point in EAOPs processes is the design of the cell/electrochemical reactors with the aim of improving PhCs removal efficiencies and reducing operational costs [105]. In this design, it is important to consider the configuration of the reactor (conventional stirred-tank cell, flow-by reactor, or flow-through reactor) as well as the geometry of the electrode (plane, mesh, foam). Gonzaga et al. [97] compared two reactor configurations (a conventional stirred-tank cell and a microfluidic flow-through reactor) in the removal of three antibiotics (penicillin G, meropenem and chloramphenicol; $50 \mathrm{mg} \mathrm{dm}^{-3}$ each) in urine by electrooxidation and photo-electrooxidation. In the microfluidic flow-through reactor, the anode support material used was a porous titanium foam (3D-electrode) and in the conventional stirred-tank cell used a titanium plate (2D-electrode). In both cases, the composition of the electrode was $\mathrm{MMO}-\mathrm{Ti} / \mathrm{RuO}_{2} \mathrm{IrO}_{2}$ and the current density was $30 \mathrm{~mA} \mathrm{~cm}^{-2}$. Results show that when using the microfluidic flow-through reactor, the reaction rate is much faster (from 2-4 times) than when using the conventional stirred tank. For example, in the photo-electrooxidation process, the conventional cell is able to remove up to $82 \%$ of each of the antibiotics at $6.4 \mathrm{Ah} \mathrm{dm}^{-3}$. However, the microfluidic cell achieves complete removal of all three antibiotics for the same applied charge. 
Another important difference is that the electrical consumption to oxidize the antibiotics in urine is about three times lower in the microfluidic flow-through. This improvement can be attributed to the larger active area of the anode (3D-foam), the improved mass transport coefficient and the decreased ohmic resistance in the microfluidic flow-through.

\section{Conclusions}

The occurrence of PhCs in water bodies has increased over the years, with hospital wastewater as the major source of these pollutants. For this reason, to preserve the aquatic environment, it is necessary to know the type and levels of PhCs contained in hospital effluents. Conventional biological processes have been tested to biodegrade antibiotics using bacteria, such as Pseudomonas aeruginosa, microbial consortium, or fungi, such as the Colombian native fungus (Leptosphaerulina sp.). In addition, different activated carbons prepared with Caesalpinia ferrea, Brazil nutshells with $\mathrm{ZnCl}_{2}$, Bertholletia excelsa or kenaf, as well as magnetic adsorbents from olive kernels (MA-OK) have been used in the adsorption process. Another conventional treatment, such as electrochemically assisted coagulation has been combined with the adsorption process using chitosan to improve the degradation efficiencies in HWW.

AOPs have also been tested for the removal of PhCs in hospital wastewater and urine. These technologies promote the generation of highly reactive species for the degradation of organic pollutants. Fenton-based processes have been employed for the removal of $\mathrm{PhCs}$ in hospital effluents using Fe, Fe-Mn binary oxide, or magnetite as catalysts. The coupling of UV light irradiation to these technologies (photo-Fenton) was checked for the removal of PhCs, in order to improve the removal efficiencies. Likewise, photocatalytic processes using $\mathrm{TiO}_{2}$ as a photo-catalyst have also been tested for the removal of PhCs in this type of effluents. On the other hand, persulfate-based AOPs have been studied for the treatment of hospital wastewater. The enhancement of these processes can be favored by the irradiation of UV light to form free sulfate radicals by the photo-activation of persulfate.

Within AOPs, EAOPs are considered as a new alternative for the degradation of $\mathrm{PhCs}$ in hospital wastewater where oxidizing species are in-situ generated from the oxidation and reduction reactions in the system. These processes can also be enhanced by the coupling of irradiation technologies (UVA, UVC and solar irradiation). Electrochemical oxidation has been extensively studied for the elimination of PhCs in hospital wastewater using different electrodes (active and non-active anodes). Likewise, the electro-Fenton process (using different anodic and cathodic materials) has proven to be a promising technology for the removal of PhCs in hospital effluents.

Author Contributions: Conceptualization: Á.M., S.C., E.L. and C.S.; methodology: Á.M. and E.L.; validation: M.A.R. and C.S.; formal analysis: Á.M., S.C. and E.L.; investigation: Á.M. and S.C., resources: P.C., M.A.R. and C.S.; data curation: Á.M. and E.L.; writing-original draft: Á.M. and S.C.; writing-review and editing: S.C. and C.S.; supervision: M.A.R. and C.S.; project administration: P.C. and C.S.; funding acquisition: P.C. and C.S. All authors have read and agreed to the published version of the manuscript.

Funding: This research was funded by Junta de Comunidades de Castilla-La Mancha (JCCM), by "ERDF A way of making Europe" (European Union), and by the Ministry of Science and Innovation (MCIN/AEI/10.13039/501100011033/) through the grants SBPLY/17/180501/000396, PID2019110904RB-I00 and EQC2018-004469-P.

Institutional Review Board Statement: Not applicable.

Informed Consent Statement: Not applicable.

Data Availability Statement: Not applicable.

Conflicts of Interest: The authors declare no conflict of interest. 


\section{References}

1. Tyagi, R.D.; Sellamuthu, B.; Tiwari, B.; Yan, S.; Drogui, P.; Zhang, X.; Pandey, A. Current Developments in Biotechnology and Bioengineering: Environmental and Health Impact of Hospital Wastewater; Elsevier Science: Amsterdam, The Netherlands, 2020.

2. Ram, S.K.; Panidepu, H.; Cheernam, V.; Tyagi, R.D. 2-Pharmaceutical metabolites and their by-products in hospital wastewater. In Current Developments in Biotechnology and Bioengineering; Tyagi, R.D., Sellamuthu, B., Tiwari, B., Yan, S., Drogui, P., Zhang, X., Pandey, A., Eds.; Elsevier: Amsterdam, The Netherlands, 2020; pp. 43-78.

3. Verlicchi, P.; Zambello, E. Predicted and measured concentrations of pharmaceuticals in hospital effluents. Examination of the strengths and weaknesses of the two approaches through the analysis of a case study. Sci. Total Environ. 2016, 565, 82-94. [CrossRef]

4. Petrovic, M.; Verlicchi, P. Water treatment plants and pharmaceutical residues in Catalonia and Italy. Contrib. Sci. 2014, 10, 135-150.

5. Kim, M.-K.; Zoh, K.-D. Occurrence and removals of micropollutants in water environment. Environ. Eng. Res. 2016, 21, 319-332. [CrossRef]

6. Mirzaei, R.; Yunesian, M.; Nasseri, S.; Gholami, M.; Jalilzadeh, E.; Shoeibi, S.; Mesdaghinia, A. Occurrence and fate of most prescribed antibiotics in different water environments of Tehran, Iran. Sci. Total Environ. 2018, 619-620, 446-459. [CrossRef]

7. Souza, F.S.; Féris, L.A. Hospital and Municipal Wastewater: Identification of Relevant Pharmaceutical Compounds. Water Environ. Res. 2016, 88, 871-877. [CrossRef]

8. Yadav, B.; González, C.S.O.; Sellamuthu, B.; Tyagi, R.D. 8-Pharmaceuticals roles in microbial evolution. In Current Developments in Biotechnology and Bioengineering; Tyagi, R.D., Sellamuthu, B., Tiwari, B., Yan, S., Drogui, P., Zhang, X., Pandey, A., Eds.; Elsevier: Amsterdam, The Netherlands, 2020; pp. 241-278.

9. Schug, T.T.; Janesick, A.; Blumberg, B.; Heindel, J.J. Endocrine disrupting chemicals and disease susceptibility. J. Steroid Biochem. Mol. Biol. 2011, 127, 204-215.

10. Kar, S.; Roy, K. Risk assessment for ecotoxicity of pharmaceuticals-an emerging issue. Expert Opin. Drug Saf. 2012, 11, 235-274. [CrossRef]

11. Rivera-Utrilla, J.; Sánchez-Polo, M.; Ferro-García, M.Á.; Prados-Joya, G.; Ocampo-Pérez, R. Pharmaceuticals as emerging contaminants and their removal from water. A review. Chemosphere 2013, 93, 1268-1287. [CrossRef]

12. Del Álamo, A.C.; González, C.; Pariente, M.I.; Molina, R.; Martínez, F. Fenton-like catalyst based on a reticulated porous perovskite material: Activity and stability for the on-site removal of pharmaceutical micropollutans in a hospital wastewater. Chem. Eng. J. 2020, 401, 126113. [CrossRef]

13. Aydin, S.; Aydin, M.E.; Ulvi, A.; Kilic, H. Antibiotics in hospital effluents: Occurrence, contribution to urban wastewater, removal in a wastewater treatment plant, and environmental risk assessment. Environ. Sci. Pollut. Res. 2019, 26, 544-558. [CrossRef] [PubMed]

14. Al Aukidy, M.; Al Chalabi, S.; Verlicchi, P. Hospital Wastewater Treatments Adopted in Asia, Africa, and Australia. In Hospital Wastewaters: Characteristics, Management, Treatment and Environmental Risks; Verlicchi, P., Ed.; Springer International Publishing: Cham, Switzerland, 2018; pp. 171-188.

15. Khetan, S.K.; Collins, T.J. Human Pharmaceuticals in the Aquatic Environment: A Challenge to Green Chemistry. Chem. Rev. 2007, 107, 2319-2364. [CrossRef]

16. Rodriguez-Mozaz, S.; Chamorro, S.; Marti, E.; Huerta, B.; Gros, M.; Sànchez-Melsió, A.; Borrego, C.M.; Barceló, D.; Balcázar, J.L. Occurrence of antibiotics and antibiotic resistance genes in hospital and urban wastewaters and their impact on the receiving river. Water Res. 2015, 69, 234-242. [CrossRef]

17. Verlicchi, P.; Galletti, A.; Petrovic, M.; Barceló, D. Hospital effluents as a source of emerging pollutants: An overview of micropollutants and sustainable treatment options. J. Hydrol. 2010, 389, 416-428. [CrossRef]

18. Arsand, D.R.; Kümmerer, K.; Martins, A.F. Removal of dexamethasone from aqueous solution and hospital wastewater by electrocoagulation. Sci. Total Environ. 2013, 443, 351-357. [CrossRef]

19. Kasperiski, F.M.; Lima, E.C.; Umpierres, C.S.; dos Reis, G.S.; Thue, P.S.; Lima, D.R.; Dias, S.L.P.; Saucier, C.; da Costa, J.B. Production of porous activated carbons from Caesalpinia ferrea seed pod wastes: Highly efficient removal of captopril from aqueous solutions. J. Clean. Prod. 2018, 197, 919-929. [CrossRef]

20. Copete-Pertuz, L.S.; Plácido, J.; Serna-Galvis, E.A.; Torres-Palma, R.A.; Mora, A. Elimination of Isoxazolyl-Penicillins antibiotics in waters by the ligninolytic native Colombian strain Leptosphaerulina sp. considerations on biodegradation process and antimicrobial activity removal. Sci. Total Environ. 2018, 630, 1195-1204. [CrossRef]

21. Ouarda, Y.; Bouchard, F.; Azaïs, A.; Vaudreuil, M.-A.; Drogui, P.; Dayal Tyagi, R.; Sauvé, S.; Buelna, G.; Dubé, R. Electrochemical treatment of real hospital wastewaters and monitoring of pharmaceutical residues by using surrogate models. J. Environ. Chem. Eng. 2019, 7, 103332. [CrossRef]

22. Lima, D.R.; Hosseini-Bandegharaei, A.; Thue, P.S.; Lima, E.C.; de Albuquerque, Y.R.T.; dos Reis, G.S.; Umpierres, C.S.; Dias, S.L.P.; Tran, H.N. Efficient acetaminophen removal from water and hospital effluents treatment by activated carbons derived from Brazil nutshells. Colloids Surf. A Physicochem. Eng. Asp. 2019, 583, 123966. [CrossRef]

23. Cotillas, S.; Lacasa, E.; Sáez, C.; Cañizares, P.; Rodrigo, M.A. Electrolytic and electro-irradiated technologies for the removal of chloramphenicol in synthetic urine with diamond anodes. Water Res. 2018, 128, 383-392. [CrossRef] [PubMed] 
24. Mackul'ak, T.; Cverenkárová, K.; Vojs Staňová, A.; Fehér, M.; Tamáš, M.; Škulcová, A.B.; Gál, M.; Naumowicz, M.; Špalková, V.; Bírošová, L. Hospital Wastewater-Source of Specific Micropollutants, Antibiotic-Resistant Microorganisms, Viruses, and Their Elimination. Antibiotics 2021, 10, 1070. [CrossRef] [PubMed]

25. Verlicchi, P.; Al Aukidy, M.; Zambello, E. Occurrence of pharmaceutical compounds in urban wastewater: Removal, mass load and environmental risk after a secondary treatment-A review. Sci. Total Environ. 2012, 429, 123-155. [CrossRef]

26. Herraiz-Carboné, M.; Cotillas, S.; Lacasa, E.; Sainz de Baranda, C.; Riquelme, E.; Cañizares, P.; Rodrigo, M.A.; Sáez, C. A review on disinfection technologies for controlling the antibiotic resistance spread. Sci. Total Environ. 2021, 797, 149150. [CrossRef]

27. Wang, J.; Shen, J.; Ye, D.; Yan, X.; Zhang, Y.; Yang, W.; Li, X.; Wang, J.; Zhang, L.; Pan, L. Disinfection technology of hospital wastes and wastewater: Suggestions for disinfection strategy during coronavirus Disease 2019 (COVID-19) pandemic in China. Environ. Pollut. 2020, 262, 114665. [CrossRef]

28. Chiang, C.F.; Tsai, C.T.; Lin, S.T.; Huo, C.P.; Lo, K.V. Disinfection of hospital wastewater by continuous ozonization. J. Environ. Sci. Health A Tox. Hazard. Subst. Environ. Eng. 2003, 38, 2895-2908. [CrossRef]

29. Majumder, A.; Gupta, A.K.; Ghosal, P.S.; Varma, M. A review on hospital wastewater treatment: A special emphasis on occurrence and removal of pharmaceutically active compounds, resistant microorganisms, and SARS-CoV-2. J. Environ. Chem Eng. 2021, 9, 104812. [CrossRef]

30. Herraiz-Carboné, M.; Lacasa, E.; Cotillas, S.; Vasileva, M.; Cañizares, P.; Rodrigo, M.A.; Sáez, C. The role of chloramines on the electrodisinfection of Klebsiella pneumoniae in hospital urines. Chem. Eng. J. 2021, 409, 128253. [CrossRef]

31. Raut, A.S.; Parker, C.B.; Klem, E.J.D.; Stoner, B.R.; Deshusses, M.A.; Glass, J.T. Reduction in energy for electrochemical disinfection of E. coli in urine simulant. J. Appl. Electrochem. 2019, 49, 443-453. [CrossRef]

32. Martínez-Huitle, C.A.; Brillas, E. A critical review over the electrochemical disinfection of bacteria in synthetic and real wastewaters using a boron-doped diamond anode. Curr. Opin. Solid State Mater. Sci. 2021, 25, 100926. [CrossRef]

33. Rivera-Gutiérrez, E.; Ramírez-García, J.J.; Pavón Romero, S.H.; Rodríguez, M.M.; Ramírez-Serrano, A.; Jiménez-Marin, A. Dicloxacillin Degradation with Free-Living Bacteria. WaterAirSoil Pollut. 2020, 231, 1-13. [CrossRef]

34. Macías-García, A.; García-Sanz-Calcedo, J.; Carrasco-Amador, J.P.; Segura-Cruz, R. Adsorption of paracetamol in hospital wastewater through activated carbon filters. Sustainability 2019, 11, 2672. [CrossRef]

35. Alidadi, H.; Dolatabadi, M.; Davoudi, M.; Barjasteh-Askari, F.; Jamali-Behnam, F.; Hosseinzadeh, A. Enhanced removal of tetracycline using modified sawdust: Optimization, isotherm, kinetics, and regeneration studies. Process. Saf. Environ. Prot. 2018, 117, 51-60. [CrossRef]

36. Lima, D.R.; Lima, E.C.; Umpierres, C.S.; Thue, P.S.; El-Chaghaby, G.A.; da Silva, R.S.; Pavan, F.A.; Dias, S.L.P.; Biron, C. Removal of amoxicillin from simulated hospital effluents by adsorption using activated carbons prepared from capsules of cashew of Para. Environ. Sci. Pollut. Res. 2019, 26, 16396-16408. [CrossRef]

37. Jafari, K.; Heidari, M.; Rahmanian, O. Wastewater treatment for Amoxicillin removal using magnetic adsorbent synthesized by ultrasound process. Ultrason. Sonochem. 2018, 45, 248-256. [CrossRef] [PubMed]

38. Esfandyari, Y.; Saeb, K.; Tavana, A.; Rahnavard, A.; Fahimi, F.G. Effective removal of cefazolin from hospital wastewater by the electrocoagulation process. Water Sci. Technol. 2019, 80, 2422-2429. [CrossRef] [PubMed]

39. Ahmadzadeh, S.; Asadipour, A.; Pournamdari, M.; Behnam, B.; Rahimi, H.R.; Dolatabadi, M. Removal of ciprofloxacin from hospital wastewater using electrocoagulation technique by aluminum electrode: Optimization and modelling through response surface methodology. Process. Saf. Environ. Prot. 2017, 109, 538-547. [CrossRef]

40. Malakootian, M.; Ahmadian, M. Removal of ciprofloxacin from aqueous solution by electro-activated persulfate oxidation using aluminum electrodes. Water Sci. Technol. 2019, 80, 587-596. [CrossRef] [PubMed]

41. Ahmadzadeh, S.; Asadipour, A.; Yoosefian, M.; Dolatabadi, M. Improved electrocoagulation process using chitosan for efficient removal of cefazolin antibiotic from hospital wastewater through sweep flocculation and adsorption: Kinetic and isotherm study. Desalin. Water Treat. 2017, 92, 160-171. [CrossRef]

42. Cristóvão, M.B.; Torrejais, J.; Janssens, R.; Luis, P.; Van der Bruggen, B.; Dubey, K.K.; Mandal, M.K.; Bronze, M.R.; Crespo, J.G.; Pereira, V.J. Treatment of anticancer drugs in hospital and wastewater effluents using nanofiltration. Sep. Purif. Technol. 2019, 224, 273-280. [CrossRef]

43. Emamjomeh, M.M.; Sivakumar, M. Review of pollutants removed by electrocoagulation and electrocoagulation/flotation processes. J. Environ. Manag. 2009, 90, 1663-1679. [CrossRef]

44. Mokhbi, Y.; Korichi, M.; Akchiche, Z. Combined photocatalytic and Fenton oxidation for oily wastewater treatment. Appl. Water Sci. 2019, 9, 35. [CrossRef]

45. Agudelo, E.A.; Cardona G., S.A. Advanced Oxidation Technology (Ozone-catalyzed by Powder Activated Carbon-Portland Cement) for the Degradation of the Meropenem Antibiotic. Ozone Sci. Eng. 2021, 43, 88-105. [CrossRef]

46. Wu, K.; Si, X.; Jiang, J.; Si, Y.; Sun, K.; Yousaf, A. Enhanced degradation of sulfamethoxazole by Fe-Mn binary oxide synergetic mediated radical reactions. Environ. Sci. Pollut. Res. 2019, 26, 14350-14361. [CrossRef]

47. Munoz, M.; Conde, J.; de Pedro, Z.M.; Casas, J.A. Antibiotics abatement in synthetic and real aqueous matrices by $\mathrm{H}_{2} \mathrm{O}_{2} / \mathrm{natural}$ magnetite. Catal. Today 2018, 313, 142-147. [CrossRef]

48. Papoutsakis, S.; Afshari, Z.; Malato, S.; Pulgarin, C. Elimination of the iodinated contrast agent iohexol in water, wastewater and urine matrices by application of photo-Fenton and ultrasound advanced oxidation processes. J. Environ. Chem. Eng. 2015, 3, 2002-2009. [CrossRef] 
49. Sanabria, P.; Scunderlick, D.; Wilde, M.L.; Lüdtke, D.S.; Sirtori, C. Solar photo-Fenton treatment of the anti-cancer drug anastrozole in different aqueous matrices at near-neutral $\mathrm{pH}$ : Transformation products identification, pathways proposal, and in silico (Q)SAR risk assessment. Sci. Total Environ. 2021, 754, 142300. [CrossRef] [PubMed]

50. Della-Flora, A.; Wilde, M.L.; Thue, P.S.; Lima, D.; Lima, E.C.; Sirtori, C. Combination of solar photo-Fenton and adsorption process for removal of the anticancer drug Flutamide and its transformation products from hospital wastewater. J. Hazard. Mater. 2020, 396, 122699. [CrossRef]

51. Jaén-Gil, A.; Buttiglieri, G.; Benito, A.; Gonzalez-Olmos, R.; Barceló, D.; Rodríguez-Mozaz, S. Metoprolol and metoprolol acid degradation in $\mathrm{UV} / \mathrm{H} 2 \mathrm{O} 2$ treated wastewaters: An integrated screening approach for the identification of hazardous transformation products. J. Hazard. Mater. 2019, 380, 120851. [CrossRef]

52. Kim, T.-K.; Kim, T.; Park, H.; Lee, I.; Jo, A.; Choi, K.; Zoh, K.-D. Degradation of ciprofloxacin and inactivation of ciprofloxacin resistant E. faecium during UV-LED (275 nm)/chlorine process. Chem. Eng. J. 2020, 394, 124803. [CrossRef]

53. Chinnaiyan, P.; Thampi, S.G.; Kumar, M.; Balachandran, M. Photocatalytic degradation of metformin and amoxicillin in synthetic hospital wastewater: Effect of classical parameters. Int. J. Environ. Sci. Technol. 2019, 16, 5463-5474. [CrossRef]

54. Guateque-Londoño, J.F.; Serna-Galvis, E.A.; Silva-Agredo, J.; Ávila-Torres, Y.; Torres-Palma, R.A. Dataset on the degradation of losartan by TiO2-photocatalysis and UVC/persulfate processes. Data Brief. 2020, 31, 105692. [CrossRef] [PubMed]

55. Gharaghani, M.A.; Malakootian, M. Photocatalytic degradation of the antibiotic ciprofloxacin by ZnO nanoparticles immobilized on a glass plate. Desalin. Water Treat. 2017, 89, 304-314. [CrossRef]

56. Ghauch, A.; Tuqan, A.M.; Kibbi, N. Naproxen abatement by thermally activated persulfate in aqueous systems. Chem. Eng. J. 2015, 279, 861-873. [CrossRef]

57. Jaén-Gil, A.; Buttiglieri, G.; Benito, A.; Mir-Tutusaus, J.A.; Gonzalez-Olmos, R.; Caminal, G.; Barceló, D.; Sarrà, M.; Rodriguez-Mozaz, S. Combining biological processes with $\mathrm{UV} / \mathrm{H} 2 \mathrm{O} 2$ for metoprolol and metoprolol acid removal in hospital wastewater. Chem. Eng. J. 2021, 404, 126482. [CrossRef]

58. Rekhate, C.V.; Srivastava, J.K. Recent advances in ozone-based advanced oxidation processes for treatment of wastewater-A review. Chem. Eng. J. Adv. 2020, 3, 100031. [CrossRef]

59. Saeid, S.; Tolvanen, P.; Kumar, N.; Eränen, K.; Peltonen, J.; Peurla, M.; Mikkola, J.P.; Franz, A.; Salmi, T. Advanced oxidation process for the removal of ibuprofen from aqueous solution: A non-catalytic and catalytic ozonation study in a semi-batch reactor. Appl. Catal. B Environ. 2018, 230, 77-90. [CrossRef]

60. Pignatello, J.J.; Oliveros, E.; MacKay, A. Advanced oxidation processes for organic contaminant destruction based on the fenton reaction and related chemistry. Crit. Rev. Environ. Sci. Technol. 2006, 36, 1-84. [CrossRef]

61. Brillas, E.; Sirés, I.; Oturan, M.A. Electro-Fenton Process and Related Electrochemical Technologies Based on Fenton's Reaction Chemistry. Chem. Rev. 2009, 109, 6570-6631. [CrossRef]

62. Sá, R.D.; Rodríguez-Pérez, A.P.; Rodrigues-Silva, F.; de Paula, V.C.S.; Prola, L.D.T.; de Freitas, A.M.; de Carvalho, K.Q.; de Liz, M.V. Treatment of a clinical analysis laboratory wastewater from a hospital by photo-Fenton process at four radiation settings and toxicity response. Environ. Sci. Pollut. Res. Int. 2021, 28, 24180-24190. [CrossRef] [PubMed]

63. Dong, W.; Sun, S.-P.; Yang, X.; Zhou, K.; Li, Y.; Wang, X.; Wu, Z.; Wu, W.D.; Chen, X.D. Enhanced emerging pharmaceuticals removal in wastewater after biotreatment by a low-pressure UVA/FeIII-EDDS $/ \mathrm{H}_{2} \mathrm{O}_{2}$ process under neutral $\mathrm{pH}$ conditions. Chem. Eng. J. 2019, 366, 539-549. [CrossRef]

64. Coledam, D.A.C.; Sánchez-Montes, I.; Silva, B.F.; Aquino, J.M. On the performance of $\mathrm{HOCl} / \mathrm{Fe}^{2+}, \mathrm{HOCl} / \mathrm{Fe}^{2+} / \mathrm{UVA}$, and $\mathrm{HOCl} / \mathrm{UVC}$ processes using in situ electrogenerated active chlorine to mineralize the herbicide picloram. Appl. Catal. B Environ. 2018, 227, 170-177. [CrossRef]

65. Gallego-Schmid, A.; Tarpani, R.R.Z.; Miralles-Cuevas, S.; Cabrera-Reina, A.; Malato, S.; Azapagic, A. Environmental assessment of solar photo-Fenton processes in combination with nanofiltration for the removal of micro-contaminants from real wastewaters. Sci. Total Environ. 2019, 650, 2210-2220. [CrossRef]

66. Miralles-Cuevas, S.; Oller, I.; Ruiz Aguirre, A.; Sánchez Pérez, J.A.; Malato Rodríguez, S. Removal of pharmaceuticals at microg L-1 by combined nanofiltration and mild solar photo-Fenton. Chem. Eng. J. 2014, 239, 68-74. [CrossRef]

67. Michael, S.G.; Michael-Kordatou, I.; Beretsou, V.G.; Jäger, T.; Michael, C.; Schwartz, T.; Fatta-Kassinos, D. Solar photo-Fenton oxidation followed by adsorption on activated carbon for the minimisation of antibiotic resistance determinants and toxicity present in urban wastewater. Appl. Catal. B Environ. 2019, 244, 871-880. [CrossRef]

68. Liao, C.H.; Gurol, M.D. Chemical Oxidation by Photolytic Decomposition of Hydrogen Peroxide. Environ. Sci. Technol. 1995, 29, 3007-3014. [CrossRef] [PubMed]

69. Jin, J.; El-Din, M.G.; Bolton, J.R. Assessment of the UV/Chlorine process as an advanced oxidation process. Water Res. 2011, 45, 1890-1896. [CrossRef]

70. Ma, H.; Brennan, A.; Diamond, S.A. Photocatalytic reactive oxygen species production and phototoxicity of titanium dioxide nanoparticles are dependent on the solar ultraviolet radiation spectrum. Environ. Toxicol. Chem. 2012, 31, 2099-2107. [CrossRef] [PubMed]

71. Fawzi Suleiman Khasawneh, O.; Palaniandy, P. Removal of organic pollutants from water by Fe2O3/TiO2 based photocatalytic degradation: A review. Environ. Technol. Innov. 2021, 21, 101230. [CrossRef]

72. Ahmadi, S.; Igwegbe, C.A.; Rahdar, S. The application of thermally activated persulfate for degradation of Acid Blue 92 in aqueous solution. Int. J. Ind. Chem. 2019, 10, 249-260. [CrossRef] 
73. Zrinyi, N.; Pham, A.L.-T. Oxidation of benzoic acid by heat-activated persulfate: Effect of temperature on transformation pathway and product distribution. Water Res. 2017, 120, 43-51. [CrossRef]

74. Loos, G.; Scheers, T.; Van Eyck, K.; Van Schepdael, A.; Adams, E.; Van der Bruggen, B.; Cabooter, D.; Dewil, R. Electrochemical oxidation of key pharmaceuticals using a boron doped diamond electrode. Sep. Purif. Technol. 2018, 195, 184-191. [CrossRef]

75. Gonzaga, I.M.D.; Moratalla, A.; Eguiluz, K.I.B.; Salazar-Banda, G.R.; Cañizares, P.; Rodrigo, M.A.; Saez, C. Influence of the doping level of boron-doped diamond anodes on the removal of penicillin G from urine matrixes. Sci. Total Environ. 2020, 736, 139536. [CrossRef] [PubMed]

76. Cotillas, S.; Lacasa, E.; Herraiz, M.; Sáez, C.; Cañizares, P.; Rodrigo, M.A. The Role of the Anode Material in Selective Penicillin G Oxidation in Urine. Chem. Electro.Chem. 2019, 6, 1376-1384. [CrossRef]

77. Kobayashi, T.; Hirose, J.; Sano, K.; Kato, R.; Ijiri, Y.; Takiuchi, H.; Tanaka, K.; Goto, E.; Tamai, H.; Nakano, T. Application of electrolysis for detoxification of an antineoplastic in urine. Ecotoxicol. Environ. Saf. 2012, 78, 123-127. [CrossRef] [PubMed]

78. Sirés, I.; Brillas, E.; Oturan, M.A.; Rodrigo, M.A.; Panizza, M. Electrochemical advanced oxidation processes: Today and tomorrow. A review. Environ. Sci. Pollut. Res. 2014, 21, 8336-8367. [CrossRef]

79. Martínez-Huitle, C.A.; Rodrigo, M.A.; Sirés, I.; Scialdone, O. Single and Coupled Electrochemical Processes and Reactors for the Abatement of Organic Water Pollutants: A Critical Review. Chem. Rev. 2015, 115, 13362-13407. [CrossRef] [PubMed]

80. dos Santos, A.J.; Cabot, P.L.; Brillas, E.; Sirés, I. A comprehensive study on the electrochemical advanced oxidation of antihypertensive captopril in different cells and aqueous matrices. Appl. Catal. B Environ. 2020, 277, 119240. [CrossRef]

81. Parra, K.N.; Gul, S.; Aquino, J.M.; Miwa, D.W.; Motheo, A.J. Electrochemical degradation of tetracycline in artificial urine medium. J. Solid State Electrochem. 2016, 20, 1001-1009. [CrossRef]

82. Perea, L.A.; Palma-Goyes, R.E.; Vazquez-Arenas, J.; Romero-Ibarra, I.; Ostos, C.; Torres-Palma, R.A. Efficient cephalexin degradation using active chlorine produced on ruthenium and iridium oxide anodes: Role of bath composition, analysis of degradation pathways and degradation extent. Sci. Total Environ. 2019, 648, 377-387. [CrossRef] [PubMed]

83. Maldonado, S.; Rodrigo, M.; Cañizares, P.; Roa, G.; Barrera, C.; Ramirez, J.; Sáez, C. On the degradation of 17- $\beta$ estradiol using boron doped diamond electrodes. Processes 2020, 8, 710. [CrossRef]

84. Cotillas, S.; Lacasa, E.; Sáez, C.; Cañizares, P.; Rodrigo, M.A. Removal of pharmaceuticals from the urine of polymedicated patients: A first approach. Chem. Eng. J. 2018, 331, 606-614. [CrossRef]

85. Serna-Galvis, E.A.; Berrio-Perlaza, K.E.; Torres-Palma, R.A. Electrochemical treatment of penicillin, cephalosporin, and fluoroquinolone antibiotics via active chlorine: Evaluation of antimicrobial activity, toxicity, matrix, and their correlation with the degradation pathways. Environ. Sci. Pollut. Res. 2017, 24, 23771-23782. [CrossRef] [PubMed]

86. Palma, R.E.; Serna-Galvis, E.; Ramirez, J.E.; Torres, R.A. Electrochemical Degradation of Naproxen (NPX) and Diclofenac (DFC) through Active Chlorine Species (Cl2-active): Considerations on Structural Aspects and Degradation in Urine. ECS Trans. 2021, 100, 55-71. [CrossRef]

87. Jojoa-Sierra, S.D.; Silva-Agredo, J.; Herrera-Calderon, E.; Torres-Palma, R.A. Elimination of the antibiotic norfloxacin in municipal wastewater, urine and seawater by electrochemical oxidation on IrO 2 anodes. Sci. Total Environ. 2017, 575, 1228-1238. [CrossRef] [PubMed]

88. Sordello, F.; Fabbri, D.; Rapa, L.; Minero, C.; Minella, M.; Vione, D. Electrochemical abatement of cefazolin: Towards a viable treatment for antibiotic-containing urine. J. Clean. Prod. 2021, 289, 125722. [CrossRef]

89. Zwiener, C.; Glauner, T.; Sturm, J.; Wörner, M.; Frimmel, F.H. Electrochemical reduction of the iodinated contrast medium iomeprol: Iodine mass balance and identification of transformation products. Anal. Bioanal. Chem. 2009, 395, 1885-1892. [CrossRef]

90. Herraiz-Carboné, M.; Cotillas, S.; Lacasa, E.; Moratalla, Á.; Cañizares, P.; Rodrigo, M.A.; Sáez, C. Improving the biodegradability of hospital urines polluted with chloramphenicol by the application of electrochemical oxidation. Sci. Total Environ. 2020, 725, 138430. [CrossRef]

91. Ouarda, Y.; Tiwari, B.; Azaïs, A.; Vaudreuil, M.-A.; Ndiaye, S.D.; Drogui, P.; Tyagi, R.D.; Sauvé, S.; Desrosiers, M.; Buelna, G.; et al. Synthetic hospital wastewater treatment by coupling submerged membrane bioreactor and electrochemical advanced oxidation process: Kinetic study and toxicity assessment. Chemosphere 2018, 193, 160-169. [CrossRef]

92. Feng, L.; Serna-Galvis, E.A.; Oturan, N.; Giannakis, S.; Torres-Palma, R.A.; Oturan, M.A. Evaluation of process influencing factors, degradation products, toxicity evolution and matrix-related effects during electro-Fenton removal of piroxicam from waters. $J$. Environ. Chem. Eng. 2019, 7, 103400. [CrossRef]

93. Ahmadzadeh, S.; Dolatabadi, M. Removal of acetaminophen from hospital wastewater using electro-Fenton process. Environ. Earth Sci. 2018, 77, 53. [CrossRef]

94. Moratalla, Á.; Araújo, D.M.; Moura, G.O.M.A.; Lacasa, E.; Cañizares, P.; Rodrigo, M.A.; Sáez, C. Pressurized electro-Fenton for the reduction of the environmental impact of antibiotics. Sep. Purif. Technol. 2021, 276, 119398. [CrossRef]

95. Gonzaga, I.M.D.; Moratalla, A.; Eguiluz, K.I.B.; Salazar-Banda, G.R.; Cañizares, P.; Rodrigo, M.A.; Saez, C. Outstanding performance of the microwave-made $\mathrm{MMO}-\mathrm{Ti} / \mathrm{RuO}_{2} \mathrm{IrO}_{2}$ anode on the removal of antimicrobial activity of Penicillin $\mathrm{G}$ by photoelectrolysis. Chem. Eng. J. 2021, 420, 129999. [CrossRef]

96. Gonzaga, I.M.D.; Moratalla, A.; Eguiluz, K.I.B.; Salazar-Banda, G.R.; Cañizares, P.; Rodrigo, M.A.; Saez, C. Novel Ti/RuO 2 IrO 2 anode to reduce the dangerousness of antibiotic polluted urines by Fenton-based processes. Chemosphere 2021, $270,129344$. [CrossRef] [PubMed] 
97. Gonzaga, I.M.D.; Dória, A.R.; Moratalla, A.; Eguiluz, K.I.B.; Salazar-Banda, G.R.; Cañizares, P.; Rodrigo, M.A.; Saez, C. Electrochemical systems equipped with 2D and 3D microwave-made anodes for the highly efficient degradation of antibiotics in urine. Electrochim. Acta 2021, 392, 139012. [CrossRef]

98. Cotillas, S.; de Vidales, M.J.M.; Llanos, J.; Sáez, C.; Cañizares, P.; Rodrigo, M.A. Electrolytic and electro-irradiated processes with diamond anodes for the oxidation of persistent pollutants and disinfection of urban treated wastewater. J. Hazard. Mater. 2016, 319, 93-101. [CrossRef] [PubMed]

99. Alfaro, M.A.Q.; Ferro, S.; Martínez-Huitle, C.A.; Vong, Y.M. Boron doped diamond electrode for the wastewater treatment. J. Braz. Chem. Soc. 2006, 17, 227-236. [CrossRef]

100. Fierro, S. Electrochemical oxidation of organic compounds in aqueous acidic media on 'active' and 'non-active' type electrodes. In Electrolysis: Theory, Types and Applications; Nova Science Publishers, Inc.: Hauppauge, NY, USA, 2010; pp. $135-209$.

101. Nidheesh, P.V.; Zhou, M.; Oturan, M.A. An overview on the removal of synthetic dyes from water by electrochemical advanced oxidation processes. Chemosphere 2018, 197, 210-227. [CrossRef]

102. Ramos, M.D.N.; Santana, C.S.; Velloso, C.C.V.; da Silva, A.H.M.; Magalhães, F.; Aguiar, A. A review on the treatment of textile industry effluents through Fenton processes. Process. Saf. Environ. Prot. 2021, 155, 366-386. [CrossRef]

103. Cotillas, S.; Clematis, D.; Cañizares, P.; Carpanese, M.P.; Rodrigo, M.A.; Panizza, M. Degradation of dye Procion Red MX-5B by electrolytic and electro-irradiated technologies using diamond electrodes. Chemosphere 2018, 199, 445-452. [CrossRef]

104. Araújo, D.M.D.; Cotillas, S.; Sáez, C.; Cañizares, P.; Martínez-Huitle, C.A.; Rodrigo, M.A. Activation by light irradiation of oxidants electrochemically generated during Rhodamine B elimination. J. Electroanal. Chem. 2015, 757, 144-149. [CrossRef]

105. Bampos, G.; Petala, A.; Frontistis, Z. Recent Trends in Pharmaceuticals Removal from Water Using Electrochemical Oxidation Processes. Environments 2021, 8, 85. [CrossRef] 